NBER WORKING PAPER SERIES

\title{
TAX LAW CHANGES, INCOME SHIFTING AND MEASURED WAGE INEQUALITY: EVIDENCE FROM INDIA
}

\author{
Jagadeesh Sivadasan \\ Joel Slemrod \\ Working Paper 12240 \\ http://www.nber.org/papers/w12240
NATIONAL BUREAU OF ECONOMIC RESEARCH
1050 Massachusetts Avenue
Cambridge, MA 02138
May 2006

University of Michigan. email: jagadees@umich.edu, jslemrod@umich.edu. We thank Abhijit Banerjee, Charles Brown, Francine Lafontaine, Sendhil Mullainathan, Padmakumar Sivadasan, and participants at seminars at the NBER and University of Michigan for comments and suggestions. All remaining errors are our own. The views expressed herein are those of the author(s) and do not necessarily reflect the views of the National Bureau of Economic Research.

(C)2006 by Jagadeesh Sivadasan and Joel Slemrod. All rights reserved. Short sections of text, not to exceed two paragraphs, may be quoted without explicit permission provided that full credit, including $\odot$ notice, is given to the source. 
Tax Law Changes, Income Shifting and Measured Wage Inequality: Evidence from India Jagadeesh Sivadasan and Joel Slemrod

NBER Working Paper No. 12240

May 2006

JEL No. H32, H25, F14, O24

\begin{abstract}
$\underline{\text { ABSTRACT }}$
We use a large dataset covering all registered plants in the manufacturing sector in India over the period 1986 to 1995 to examine the effects of a 1992 income tax law change that eliminated the double taxation of wages paid to partners in partnership firms. This tax law change provides a unique opportunity to identify the effects of tax policy changes on firm behavior in a developing country context. Since the change provided incentives for shifting income from wages to profits, it also has important implications for certain measures of wage inequality. We find an immediate and pervasive response by partnership firms to the tax law change, reflected in a significant shifting of income from profits to managerial wages. Since about 50 percent of registered manufacturing plants are incorporated in the form of partnerships (including most family-run businesses), income shifting by these firms could have a significant impact on measured wage inequality. We find a sizeable jump in the mean and median relative wage of skilled workers (which includes managers and partners) following the tax law change in 1992. This sudden increase in measured wage inequality follows major trade liberalization and deregulation reforms announced earlier (in July 1991). We find that the income shifting induced by the tax law change explains almost all of the observed increase in measured wage inequality following these reforms. This finding is robust to inclusion of controls for a number of other potential sources of post-liberalization increases in wage inequality. Our results show that firms respond strongly to tax incentives for income shifting, and highlight the need to control for the potential effects of tax incentives in studies of wage inequality.
\end{abstract}

Jagadeesh Sivadasan

Stephen M. Ross School of Business

University of Michigan

701 Tappan Street, Room W7719

Ann Arbor, MI 48109-1234

jagadees@umich.edu

Joel Slemrod

Stephen M. Ross School of Business

University of Michigan

701 Tappan Street, Room W7719

Ann Arbor, MI 48109-1234

and NBER

jslemrod@umich.edu 


\section{Introduction}

In this paper, we investigate the effects of changes in Indian tax law regarding partnerships on income shifting and measured wage inequality using a survey dataset covering the entire Indian manufacturing sector for the nine-year period from 1987 to 1995. The tax law change, introduced in 1992, increased incentives for partners to pay themselves wages and salaries, instead of taking income mainly as share of profits. This tax law change provides a unique opportunity to study two important issues: how firms modify their behavior in response to tax incentives, in a developing country context, and how income shifting affects measured wage inequality, which could be relevant for a number of studies that study wage inequality using data similar to ours.

Tax policy is often used to modify firm behavior, especially in developing countries. However, conclusions about the effectiveness of tax policy instruments are often confounded by the effects of unrelated concurrent macro-economic changes or introduction of other reform measures (see Epifani (2003) or Tybout (2001) for a discussion in the context of import tax liberalizations). Because the tax law change we study affected only partnership firms, we are able to use non-partnership firms as a control group, and identify the effects of the tax law using a difference-in-differences strategy. This approach compares the behavior of partnership firms to other establishments of similar size belonging to the same industry located in the same state. Because macroeconomic shocks and other reforms are very likely to affect all establishments in the same size-industry-location group in a similar fashion, we are able to identify the effects of the tax law change separate from other confounding changes.

To document the direct effects on the tax law change, we examine four measures that reflect the extent of income shifting: (1) the fraction of non-salaried owners; (2) the profits-to-sales ratio; (3) the wages-to-sales ratio; and (4) the white-collar wages-to-profits ratio. As a model of the incentives caused by the tax system suggests, we find that the fraction of non-salaried owners falls sharply, and the white-collar wages-to- profits ratio rises significantly in 1992-93, the first year that the new tax laws took effect. There is also a drop in the profits-to-sales ratio, and an increase in wages-to-sales ratio following the tax law change. These are difference-indifferences effects on partnership firms, controlling for shocks to specific industries, locations and size quartiles using state-industry-size-year effects.

Because the tax law change caused a shift in income for partners from profits to wages, it had an impact on measured wage inequality. Partner wages get added to the observed total white-collar wage bill in the data, which leads to an increase in the measured skill premium (the ratio of the white-collar wage rate to the blue-collar wage rate $^{1}$ ) and in the ratio of the white-collar wage bill to total wages.

Coincidentally, the tax law changes were introduced just a few months after a sweeping trade (and other market) liberalization announced in July 1991. This timing is critically important because the behavioral response to the tax law changes could impact an analysis of the effect of the trade liberalization. Indeed, the effect of free-market policies and trade liberalization on inequality is a subject of an intense ongoing debate. A number of studies have documented an increase in wage inequality (usually measured as skill premium) in developing countries following trade

\footnotetext{
${ }^{1}$ The white-collar wage rate is obtained by dividing the total wage bill by the number of white-collar employees. The blue-collar wage rate is obtained similarly.
} 
expansion. While observed increases in the skill premium are puzzling from the point of view of the simplest Heckscher-Ohlin trade model, a number of alternative theoretical explanations have been proposed. ${ }^{2}$ As discussed in the survey by Goldberg and Pavcnik (2004), potential causes for increasing wage inequality following trade liberalization include Stolper-Samuelson effects due to reduction in tariffs for unskilled-intensive industries, foreign direct investment (FDI) generating additional demand for skilled workers, skill-biased technological change, or quality upgrading by firms within industries.

Note that none of these trade-liberalization related explanations for increases in wage inequality suggests that the effect would depend on the form of organization of the firm. Thus, since the tax law changes were applicable only to partnership firms, we are able to adopt a difference-indifferences strategy to distinguish the effect of the tax law change from these alternative causes for increases in measured wage inequality.

Our examination of the trends over the 1987-1995 period reveals a sharp increase in the mean and in various percentiles of the distribution of the log skill premium in 1993. We find similar effects on the share of white-collar wages in the total wage bill. Examination of these trends across different forms of organization shows that the overall effects were largely driven by changes within partnership firms, suggesting that the tax law change was responsible for the observed spikes in measured inequality. This is confirmed by regression analyses that control specifically for tariff changes, export and import orientation, FDI liberalization, distance to the frontier, and capital intensity. We find that almost all (6.5 percent of the 7.3 percent mean increase in the log skill premium) is driven by changes to partnership firms. ${ }^{3}$ Similarly, we find that most of the increase (3.55 percent out of 4.63 percent) in the overall mean white-collar share of the wage bill is driven by changes within partnership firms. Both of these findings are robust to the inclusion of various controls and industry-location-size year effects. ${ }^{4}$ We conclude that the increase in the measured skill premium and the white-collar share of the wage bill that occurred beginning in 1992 were driven primarily by income shifting by owners in partnership firms.

Our paper contributes to the literature on behavioral responses to tax distortions. ${ }^{5}$ The general topic of income shifting has been studied intensively by public finance scholars, although the empirical work relies heavily on United States data, and, to a lesser extent, European data. Large literatures have studied the extent to which the use of corporate debt finance (which shifts income from the corporate to personal tax base) responds to the tax advantages of doing so, and on the shift of firms and taxable income between corporate and non-corporate status. This study is, to our knowledge, the first such paper that documents income shifting in a developing country context. Our finding of a strong and immediate response to the incentive to shift income from profits to wages is consistent with Slemrod's (1990) classification of income shifting in the highest tier of a hierarchy of behavioral responses to tax policy changes. We find that adoption of the income shifting response was immediate and pervasive across both rural and urban areas

\footnotetext{
${ }^{2}$ See Kremer and Maskin (2003) or Goldberg and Pavcnik (2004) for surveys of this literature.

${ }^{3} \mathrm{~A}$ very small part of the change seems to be caused by changes specific to import-oriented sectors. Also, in the individual specification, there seems to be a relative decrease in skill premium in industries further away from the frontier (consistent with theory); however this effect is not present in the full specification.

${ }^{4}$ One other factor that appears important here is capital deepening coupled with an increase in the skill premium for capital intensive firms in the post-1992 period (accounting for about 0.6 percent of the total change of 4.63 percent in white-collar share of the wage bill).

${ }^{5}$ Gordon and Slemrod (2000) provides an overview of this literature.
} 
as well as young and old firms.

In the public finance literature, the question examined by Gordon and Slemrod (2000) is closest to that of this paper. It investigates shifting of income between the corporate and personal tax base, and presents evidence that a substantial amount of income shifting occurred in the United States between the mid-1960s and the mid-1990s. This evidence is based on time-series regression analyses which reveal that an increase in corporate tax rates relative to personal tax rates resulted in an increase both in reported personal income and a drop in reported corporate income. Gordon and Slemrod (2000) focus on one mechanism for shifting - changing the form of compensation for executives and other workers, such as between wage compensation and greater use of stock options. They argue that increased income shifting could help explain two well-noted phenomena occurring in the United States over this period - increasing concentration of personal income and the declining rate of corporate profitability. Because personal income appears fully on individual tax returns but corporate income appears only indirectly through dividend receipts and realized capital gains, the observed shift of income to the personal base of high-income firm owners will increase inequality as measured by income that shows up on individual tax returns. In the Indian case we study here, a shift from partnership income to salaries should not affect total personal income that shows up on personal tax returns, and so inequality measures based on personal income tax returns should be unaffected.

This paper also contributes to the literature examining changes in the effect of trade liberalization on wage inequality and highlights the need to check for changes in the tax environment when studying changes in skill premia or skill intensity, especially when using manufacturing survey data. ${ }^{6}$ Our results thus provide a cautionary tale for event studies of regulatory changes in general, and studies of trade liberalization in particular. To be sure, this potential weakness of before-after studies of trade liberalization has been pointed out before; for example, Tybout (2001) and Epifani (2003) argued that trade liberalization is often accompanied by a number of other macroeconomic and product market reform policies, and discussed the difficulty with which such studies can separately identify the effects of different types of reforms.

Finally, our paper sheds some light on the effect of liberalization on inequality in India. We find that, controlling for the spurious increase in measured wage inequality induced by tax law changes, there was little increase in wage inequality following the trade liberalization. Thus, the 1991 reforms do not appear to have significantly worsened wage inequality in the registered manufacturing sector, at least over the four-year period following the reforms covered by our data. Because our study addresses measured wage inequality in the registered manufacturing sector only, our results must be interpreted with considerable caution with regard to its implications for overall inequality (see discussion in Section 7).

The rest of the paper is organized as follows. In the next section (Section 2), we briefly describe the relevant tax law changes introduced in the Finance Act of 1992, and the trade

\footnotetext{
${ }^{6} \mathrm{~A}$ number of studies in different countries have used manufacturing survey data to examine wage inequality and the skill premium. Examples include Berman, Bound, and Griliches (1994) for the United States; Feenstra and Hanson (1997), Revenga (1997), and Hanson and Harrison (1999) for Mexico; and Pavcnik (2003) for Chile. Household-survey-based studies of income inequality would not be affected by income shifting, unless they are affected by relative misreporting of different kinds of income. Similarly, income inequality studies based on data on total taxable income (say from income tax sources) would not be biased; however, such data at the individual level are typically confidential. Income inequality analysis using publicly-available aggregate tax return data should also not be biased by income shifting, but could be biased by improvements in tax collection (Banerjee and Piketty 2005).
} 
and other reforms introduced beginning in July 1991. In Section 3, we present a brief model capturing the implications of the tax reform for income shifting and measured wage inequality, and then describe different theories relating trade liberalization to increases in wage inequality. We describe the data and define the key variables used in our study in Section 4. In Section 5 , we present empirical evidence on the direct income shifting consequences of the tax law change. In Section 6, we present empirical analysis of the trends in wage inequality and the extent to which these trends can be explained by alternative trade theories. Section 7 summarizes our results, and concludes.

\section{Tax and Trade Reforms in the Early 1990s}

\subsection{Alternative Business Forms and the Tax Reforms of 1992}

\subsubsection{Alternative Business Forms}

The three major choices for organizing a business in India are: ${ }^{7}$ (1) individual proprietorships; (2) partnerships, and (3) companies ("private or public limited companies"). The individual proprietorship form is used by entrepreneurs who have sole ownership of the establishment. For establishments with multiple owners/shareholders, the two available alternatives for organization were options (2) and (3) above. In the pre-1992 period, the key benefit from choosing the "partnership" form versus a "private or public limited company" form was that the entity-level tax rates were significantly lower on partnerships (a top rate of 18 percent for partnerships versus 45 to 50 percent for companies - see Table 3). However, the key non-tax disadvantage of this form of organization was that the liability for partners was not limited. After 1992, the difference in the tax rate between companies and partnerships narrowed considerably. ${ }^{8}$

The distribution of manufacturing sector establishments across different business forms for the year 1991 (the midpoint in our data period) is summarized in Table 2. As is evident from the table, the predominant form of business organization was the partnership form (50 percent), followed by companies (25.8 percent) and individual proprietorships (17.4 percent). Other forms include trusts, cooperatives and government departmental enterprises. In terms of total employment, companies constituted the biggest share (50.9 percent), followed by others (24.9 percent), ${ }^{9}$ partnerships (19.3 percent), and individual proprietorships (4.9 percent).

\subsubsection{Tax Reforms of 1992}

The main statute governing income taxes is the Income Tax Act (1961). Every year, the government (or specifically, the Minister of Finance), proposes a budget (technically the "Finance Act") in February/March, which announces tax rates applicable for the tax year beginning April 1 of that year. Thus, the Finance Act of 1992, would announce tax rates applicable for the fiscal year 1992-93 (April 1, 1992 to March 31, 1993), defined as 1993 in our dataset and all our

\footnotetext{
${ }^{7}$ See Chapter 3 of Ramani et al. (2004) for a detailed discussion of alternative business forms; most of the discussion there is applicable to the period we study. One key change was the tax treatment of partnership profits and salaries to partners. This is discussed in the section below.

${ }^{8}$ See also the discussion in footnote 15 . While there is a small trend towards the "corporate" form, there was no change in our dataset in this trend around the 1992 tax law change.

${ }^{9}$ Employment within others is dominated by Government Departmental Enterprises.
} 
analysis. $^{10}$

Immediately prior to 1992-93, key provisions of the Indian Income Tax Act (1961), along with the rates announced in the Annual Finance Acts (or "Budgets"), implied the following tax treatment of remuneration and profits of partners in partnership firms:

- Profits of the firm were taxed twice. First, the firm had to pay an entity-level tax on profits at the rate specified for registered (partnership) firms. ${ }^{11}$ Additionally, each partner's share of the after-entity-tax profits was to be added to the personal income of the partners and subject to tax at the rate specified for individuals of the applicable income level.

- Any payment of interest, salary, bonus, commission, or remuneration made by the firm to any partner of the firm was not deductible from revenues in the determination of the firm's taxable profits.

One effect of these provisions was that there was a tax disincentive to paying salaries to partners of the firms (regardless of whether they worked at the firm). Any salary (or other type of remuneration) would be taxed three times - first as profit at the hands of the firm (since salaries were not deductible), second as profit from business in the hands of the partner, and third as salary income in the hands of the partner. ${ }^{12}$

The double taxation of partnership profits was introduced in the Finance Act of 1956, and was critiqued as early as 1958 by the Law Commission in their 12th Report. ${ }^{13}$ However, the double taxation provisions were retained in the tax code until 1992. ${ }^{14}$ As discussed in the tax reform committee's Interim Report (1991), the primary reason for introducing a separate tax at the partnership entity level was the concern that partners would be able to manipulate their tax liability by "including relatives and friends as partners, some of whom may merely be their "benamidars," or namelenders. ${ }^{15}$

In early 1992, reports submitted by a committee set up to review Indian tax laws (called the Chelliah Committee, after its chairman Raja J. Chelliah) made a number of recommendations,

\footnotetext{
${ }^{10}$ Technically, the rates are stated in the Income Tax Department publications as applicable for the next "assessment year," to be applied to the "prior year." Thus, tax rates announced in the Finance Act 1992 would be for the "assessment year" 1993-94, but would be applicable on income earned in 1992-93 (the "prior year" for the "assessment year" 1993-94). The Finance Act would also often amend parts of the Income Tax Act. Procedures and rules are outlined in the Income Tax Rules, 1962 , and are revised through amendments to these rules, and through circulars and notifications.

${ }^{11}$ There are separate provisions relating to unregistered firms. Since our dataset covers only registered establishments, we will restrict attention to provisions for registered firms.

12 The tax treatment of remuneration paid to the partners is not specifically referred to in the Income Tax Act prior to 1992. The only reference to remuneration of partners is to specify that these payments are not deductible when calculating a partnership firm's taxable income (see section 40, Income Tax, 1991). After 1992, it is specifically stated in the Income Tax Act that remuneration to a partner would be treated as "Profits and Gains from Business or Profession" and added to the partner's total taxable income (to the extent that these were deductible in the calculation of the firm's taxable income). In the absence of these specific exceptions, in the pre-1992 period salaries paid to a partner (like any other employee's salary) would have to be added to his total income.

${ }^{13}$ The Law Commission was set up by the central government to recommend revision and updating of laws to serve the changing needs of the country.

${ }^{14}$ The taxation of income at the partnership level is unusual, compared to the practice in the United States, where partnership income is not taxed at the business entity level, while each partner's share of the firm's profits is included in their taxable income.

${ }^{15}$ This concern was especially significant in India where tracking and collecting taxes at the individual "benamidar" partner level would have been administratively quite difficult (due to the lack of social security numbers or other tracking information). Prior to 1992, even with entity level taxation, the partnership firms had incentives to use benamidars to reduce each partner's share of profits. Note that the double taxation of profits was not unusual relative to other business forms. Under the alternate organization as a "company," profits paid out as dividends to shareholders were also subject to double taxation (first as profits in the hands of the company, and then as income at the individual level). Since tax rates on profits for partnerships were lower than for companies (see Table 2), the net tax paid on profits received by the owners was lower for Partnerships. Also, tax paid by the partnership was deducted from the firm's profits before allocation in the hands of the partners.
} 
including the abolition of the partnership double taxation provision. Two key drawbacks of the pre-reform tax provisions highlighted by the committee were (1) double taxation, and (2) excessive administrative burdens stemming from rectifying partners' tax assessments due to changes in declared income of the firm. Accordingly the reforms were intended to make the tax code "more equitable" and to reduce the administrative burden on the system. Following the recommendations, a number of amendments to provisions in the Income Tax Act relating to registered partnerships were introduced in the Finance Act of 1992. The key changes (applicable for income earned in the period April 1, 1992, to March 31, 1993, and subsequently) were the following:

- Partnerships were allowed to deduct remuneration paid to "working" partners, within specified limits. As per the Income Tax Act, 1961, a "working partner" was defined as an "individual who is actively engaged in conducting the affairs of the business or profession of the firm of which he is a partner." These payments had to be authorized by the partnership deeds. $^{16}$

- Profits of partnerships would be taxed only once, at the rate specified for the partnership firm. These profits would then be exempt from any further tax. In particular, the partners' share of post-entity-tax profits would not be included in their taxable income.

- Remuneration paid to partners were to be added to their personal income but only up to the limit that was deductible while calculating the firm's taxable income (see appendix 1 for these specified limits). Thus, remuneration in excess of the specified limit, which was not allowed to be deducted while calculating taxable profits for the firm, would also only be taxed once - in the hands of the partnership firm at the rate applicable to such firms.

Notably, the Finance Act also substantially raised the entity-level tax rate on partnerships, from a range of 10 to 18 percent in 1992 to a flat 40 percent beginning in 1993 . The relevant tax rates on individuals, partnerships, and other companies are provided in Table 3.

The net impact of the changes (specifically the provision allowing salaries to "working" partners to be deducted while calculating taxable profits, and the provision ruling out double taxation of non-deductible remuneration) was to remove the disincentives related to paying salaries to partners. Starting in 1992-93, the tax rate on income up to INR 100,000 (about USD 3500) was less than the tax rate on corporate income (see Table 3), so there was a positive tax incentive to pay out some amount of salary to working partners. ${ }^{17}$ The tax rates on other business forms did not change substantially at this time (and during the period of our study); the tax rate on various income brackets for individuals, which also affects single proprietorships, did decline somewhat in $1992-93 .^{18}$

\footnotetext{
${ }^{16}$ From Explanation (4) under sub-clause (v) of clause (b) of section 40 of the Income Tax Act, 1961, and notification S.O. 1986 issued August 26, 1993. An appendix with relevant extracts from the Income Tax Act 1961 is available on request from the authors.

${ }^{17}$ Also, there was a standard deduction allowed on salary income (but not on income from business profits), which could have provided further incentives to pay out salaries to working partners.

18 Note that while the tax reform eliminated double taxation, this was done by retaining taxation on partnerships at the entity level. Thus, the change did not provide any significant additional incentives to hire "benamidar" partners. Interestingly, the Interim Report (1991) had recommended that tax at the partnership entity level be eliminated, and each partner's share of entity profits be taxed at the individual level. The committee recognized that this could provide incentives to use semi-fictional ("benamidar") partners. With taxation only at the individual level, each partner's share of the income could be reduced by adding "benamidar" partners, thus lowering tax liability for the true partners at the individual level. (While this could potentially be offset by taxes on the income of the "benamidar" partners, in practice it would be administratively complex to
} 
We model the impact of the tax provisions and the predicted behavioral response in Section 3.1 .

\subsection{Trade Liberalization and Other Economic Reforms of 1991}

Significant reforms were introduced in 1991 that transitioned India from a closed, socialist economy to a more open, free-market oriented system. The proximate cause for the reforms was a severe balance of payments crisis in 1991. In June 1991 a new government came into power following mid-term elections; this government obtained funding from the international financial institutions (the IMF, the World Bank, and The Asian Development Bank) and initiated a structural adjustment program on the advice of these institutions.

The three major reforms impacting the manufacturing sector were the liberalization of industrial, foreign investment, and trade policies regulations. ${ }^{19}$ The major industrial policy change was the extensive liberalization of licensing requirements for establishing and expanding capacity, a cornerstone of the pre-1991 industrial regulatory regime (which came to be called the "licence raj"). ${ }^{20}$ A modest easing of licensing norms had been undertaken in the late 1980s, and the industrial policy announced in 1991 extended de-licensing to almost all industries in the manufacturing sector. Another key reform announced in July 1991 was the significant relaxation of Foreign Direct Investment (FDI) regulations, especially for investments into designated high priority industries (known as "Appendix I industries"). The third major reform was the reduction in tariff rates across the board over the early 1990s. The rates dropped from an (unweighted) average of about 85 percent in 1990 to about 60 percent in 1992. There was also a devaluation of the rupee by about 41 percent during the calendar year 1991 (from about INR 18.4/USD to about INR 25.8/USD), which counteracted the effect of the tariff reductions on import-competing industries, and gave a boost for exporting firms.

Other pro-market macroeconomic policies initiated in 1991 included moves to reduce the fiscal deficit, liberalization of technology and capital goods imports, devaluation of the local currency, transition to a market determined exchange rate and liberalization of capital markets. Since these reforms were pervasive and announced simultaneously, their effects are difficult to disentangle from each other and from other macroeconomic shocks. We discuss different theoretical explanations for increases in wage inequality following trade liberalization in Section 3.2.

\section{Tax Law Changes, Trade Liberalization, and Wage Inequality}

\subsection{A Model of Behavioral Responses to the 1992 Tax Reform}

We consider a simple model that captures the key elements of the 1992 tax law and tax rate changes and predicts the behavioral responses of the partnerships affected by the tax law change.

\footnotetext{
track and collect taxes from such persons.) The Interim Report suggested that this issue be addressed using a separate act that prohibited the use of "Benamidars" (the Benami Transactions (Prohibition) Act, 1988), instead of distorting the tax structure. Since the implemented reforms retained entity level taxes, we do not expect to find a big increase in the number of partners in partnerships. This was confirmed by our analysis of the white-collar share of employment in partnership firms: we found no significant increase in the white-collar share of employment relative to other firms within the same state-industry cells.

${ }^{19}$ For a more extensive discussion of these and other reforms initiated in 1991 and continued through the 1990s, see Acharya (2002).

${ }^{20}$ For interesting anecdotal evidence on the significance of these reforms, see DeLong (2001).
} 


\subsubsection{Model Setup}

We begin by taking the choice of business form as exogenous. While this choice could be affected by tax regulations (see e.g., MacKie-Mason and Gordon, 1997), our focus here is mainly on income shifting within firms. ${ }^{21}$ Assume that a partnership generates a surplus per partner of $S$. The $\mathrm{K}$ identical partners need to choose an amount $X$ to pay themselves as wages, while the remaining $S-X$ of the surplus becomes profit that accrue to the partners. The optimal value of $X$, denoted $X^{*}$, is chosen to maximize the after-tax income of the typical partner. In a world without taxes on wages or profits, the $X$ choice would be trivial: the partners would be indifferent between paying themselves wages or receiving a share of the firm's profits.

\subsubsection{Behavior in the Pre-92 and Post-1992 Tax Regimes}

The tax system alters this indifference. To see this, note that the after-tax income per partner in the pre-1992 regime was given by:

$$
\Pi=S\left[1-t_{f}(P)\right]\left[1-t_{i}(I)\right]-X t_{i}(I)+G\left[1-t_{i}(I)\right],
$$

where $t_{i}(I)$ is the average tax rate on the partner's individual taxable income, which is a function of the level of the partner's taxable income $I ; t_{f}(P)$ is the average tax rate on the income of partnerships, which is a function of the level of the partnership's total income $P(=K S)$; and $\mathrm{G}$ is outside income for the typical partner. Here, the partner's individual taxable income $I$ equals $S\left(1-t_{f}(P)\right)+X+G$. . Defining $\tilde{S} \equiv S\left(1-t_{f}(P)\right)$, after entity-tax partnership income, we have:

$$
t_{i}(I) \equiv \frac{\int_{0}^{I} t_{m}(r) d r}{I}=\frac{\int_{0}^{\tilde{S}+X+G} t_{m}(r) d r}{\tilde{S}+X+G}
$$

where $t_{m}(r)$ is the marginal individual tax rate when the income level is $r$. Since the marginal tax rate increases with income (see Table 3 for details), the average tax rate increases with $I$ and $X$. Also, since the salary paid to each partner $(X)$ is not deductible in the pre-1992 period, $P$ and $t_{f}(P)$ are independent of $X$. Given these facts, we get from Equation 1 that $\frac{d \Pi}{d X}<0$, so that $X^{*}$ is zero. ${ }^{22}$ Thus in the pre-1992 regime, no salary should be paid to the partners.

In the post-1992 regime, wages paid to partners were deductible, as long as they were below a specified fraction of total profits (see Appendix 1 for the specified limits). Wages above this cap, while not deductible in the calculation of the firm's taxable income, were exempt from individual income tax in the hands of the partner. Defining $\mu$ as $\frac{X}{S}$, we simplify the prescribed limits as one cap, specified as a fraction of the surplus $(\bar{\mu})$. Thus, after-tax income received per partner in

\footnotetext{
${ }^{21}$ Another reason for abstracting from the choice of business organizational form is that we find no significant changes in the distribution of business forms around the time of the tax law change. (Logit and probit models of the choice of the partnership form of organization, not reported here but available from the authors, indicate that there was a downward trend in the propensity to operate as a partnership, but suggest no break in the trend around or after the introduction of the tax law change in 1992). This is consistent with the fact that the new law did not alter the total tax on partnership income significantly, just the form of taxation, and by doing so affected the incentives to shift income but not the incentive to operate in one form versus another.

${ }^{22}$ From Equations 1 and 2, after some algebra we get:

$\frac{d \Pi}{d X}=-t_{i}(I)-I\left(\frac{d t_{i}(I)}{d X}\right)=-t_{i}(I)-I\left[\frac{-\int_{0}^{I} t_{m}(r) d r}{I^{2}}+\frac{t_{m}(I)}{I}\right]=-t_{m}(I)<0$.
} 
the post-1992 regime equals:

$$
\begin{aligned}
\Pi(X) & =S-t_{f}^{\prime}(P)(S-X)-t_{i}^{\prime}(I) X+G\left[1-t_{i}^{\prime}(I)\right] \\
& =S\left[1-t_{f}^{\prime}(P)\right]+X\left[t_{f}^{\prime}(P)-t_{i}^{\prime}(I)\right]+G\left[1-t_{i}^{\prime}(I)\right],
\end{aligned}
$$

where $X \leq \bar{\mu} S$, and $t_{f}^{\prime}(P)$ and $t_{i}^{\prime}(I)$ denote post-1992 average partnership and individual tax rates at the partnership income level of $\mathrm{P}$ and the partner's individual income level of $I$, respectively. Because after 1992 the tax on partnership profits was changed to a flat rate (see Table 3 ), we have $t_{f}^{\prime}(P)=t_{f}^{\prime}$ (constant, independent of $\mathrm{P}$ ). Also, post-1992 partnership profits were not taxed again in the hands of the partner, so $I=X+G$, and accordingly we have:

$$
t_{i}^{\prime}(I) \equiv \frac{\int_{0}^{I} t_{m}^{\prime}(r) d r}{I}=\frac{\int_{0}^{X+G} t_{m}^{\prime}(r) d r}{X+G}
$$

where $t_{m}^{\prime}(r)$ is the post-1992 marginal tax rate at an income level of $r$. Therefore, we get:

$$
\begin{aligned}
\frac{d \Pi(X \mid X \leq \bar{\mu} S)}{d X} & =t_{f}^{\prime}-t_{i}^{\prime}(I)-t_{m}^{\prime}(I)+t_{i}^{\prime}(I) \\
& =t_{f}^{\prime}-t_{m}^{\prime}(I) \\
\text { and } \frac{d \Pi(X \mid X>\bar{\mu} S)}{d X} & =0 .
\end{aligned}
$$

Note that $t_{f}^{\prime}$ is a constant at 0.40 (see Table 2), and that $t_{m}^{\prime}$ increases in steps as the income of the partner increases. Thus, as $X$ goes up, so does the marginal individual income tax rate $t_{m}^{\prime}$.

Given these facts, equation 5 implies that so long as the marginal individual tax rate applicable for the partner $\left(t_{m}^{\prime}\right)$ is below the tax rate applicable to the firm's income $\left(t_{f}^{\prime}=0.40\right)$, each partner's post-tax income is increasing in $X$. Equation 6 indicates that once $X$ exceeds the prescribed limit $\bar{\mu} S$, the partners would be indifferent about the choice of $X$. Thus, the optimal choice would be to increase $X^{*}$ until the marginal tax rate applicable to the partner's personal income is just equal to the tax rate on the partnership firm. ${ }^{23}$ Thus the decision rule is:

$$
X^{*}: t_{m}^{\prime}\left(X^{*}+G\right)=t_{f}^{\prime}
$$

Based on this, we obtain the following predictions about post-1992 optimal behavior:

1. If $G$ is small enough so that $t_{m}^{\prime}(G)<0.40$, then $X^{*}>0$. From Table 2 , this means that for 1992-93, 1993-94, and 1994-95, all partners whose outside income is less than INR 100,000 ( $\simeq$ USD 3500) would choose to pay themselves positive wages. Thus, for years 1992-93 to 1994-95, at equilibrium we would have $X^{*}+G \geq$ INR 100,000, because at income levels exceeding INR 100,000, the tax rate $t_{m}^{\prime}=0.40=t_{f}^{\prime}$.

2. Assuming at least some partners have $G<$ INR 100,000, the number of salaried partners post-1992 should be positive. If the designation of working partners is flexible (not subject to scrutiny or challenge by the tax authorities), we expect the number of partners receiving wages to equal the number of partners for whom outside income < INR 100,000.

3. Assuming at least some partners have $G<$ INR 100,000 ( $\simeq$ USD 3500), declared profit for the partnership is less than $S$.

\footnotetext{
${ }^{23}$ This reasoning assumes that $S>0$.
} 
These behavioral responses will lead to the following observations for partnerships:

1. Unpaid (non-salaried) owners (proprietors and family members) as a fraction of total whitecollar employment should go down. If the tax law change is understood and acted on immediately by all firms, we should see a big downward adjustment in 1992-93, and little change thereafter.

2. Declared profits should go down after the tax law change (holding other factors constant), as some profits are shifted to wage income for the proprietors. Thus, profits as a proportion of sales should go down, and the total wage bill as a proportion of sales should go up after the tax law change.

3. The ratio of white-collar wage bill (which includes wages to all white-collar employees, including partners) to profits should go up.

Because the tax law changes were relevant only for partnership firms, we expect the above predictions to hold for this type of firm, and expect no similar changes for firms that have a different business form. This allows us to implement a difference-in-differences strategy by using the time-series of non-partnership data to serve as a control for the partnership data. ${ }^{24}$

\subsubsection{Effects on Measured Wage Inequality of Predicted Response to the 1992 Tax Law Change}

Tax induced income shifting will affect measured wage inequality. To see this, assume that both the white-collar $\left(W_{w}\right)$ and blue- collar wage $\left(W_{b}\right)$ rate stays the same $\left(W_{w}^{\prime}=W_{w}, W_{b}^{\prime}=W_{b}\right)$ in the periods before and after the tax law change (i.e., we abstract from any factor that could change blue and/or white- collar wage rates). The observed white-collar share of the wage bill in the pre-1992 regime is:

$$
w_{\text {sre92 }}=\frac{W_{w} M}{W_{w} M+W_{b} N}
$$

where $M$ is the number of salaried white-collar (non-production) employees and $N$ is the number of blue-collar employees. In the post-1992 tax regime this becomes:

$$
w s h_{\text {post } 92}=\frac{W_{w} M+X K}{W_{w} M+W_{b} N+X K},
$$

where $X K$ is the total amount of partnership profits shifted to white-collar wage and salary income, and $\mathrm{K}$ is the number of newly paid partners. Clearly, wsh $h_{\text {post } 92}>w_{s h} h_{\text {pre } 92}{ }^{25}$ Thus, as a result of the shifting of income from profits to wages by working partners induced by the 1992 tax law change, we expect the white-collar share of wages to go up.

\footnotetext{
${ }^{24}$ One issue that could impact our analysis is the significant administrative difficulties in taxing income at the individual level in India. One way to model this would be to assume that the effective marginal tax on individual income is $\gamma t_{m}(I)$, where $\gamma \in[0,1]$ captures a range of outcomes between full compliance $(\gamma=1)$ and full tax evasion $(\gamma=0)$ on salary income. For all values of $\gamma>0$ our basic results above would hold: there would be no incentive to pay any wage to partners in the pre-1992 period, while there would be an incentive to pay wages in the post-1992 period. In fact with lower effective taxation of salary income, there would be stronger incentives to pay out wages to partners in the post-92 period because the optimal $X^{*}$ would increase as $\gamma$ decreases (since the optimal $X^{*}$ is given by $t_{f}^{\prime}=\gamma t_{m}^{\prime}\left(X^{*}+G\right)$, and $t_{m}^{\prime}\left(X^{*}+G\right)$ is increasing in $X^{*}$ ). With complete tax evasion on salary income, $\gamma=0$, in the pre-1992 period, partnerships would be indifferent about $X^{*}$, while in the post-1992 period, partnerships would have an incentive to pay out the maximum amount of allowable wage income (i.e., $\left.X^{*}=\bar{\mu} S\right)$.

${ }^{25}$ Since $w_{\text {sh }} h_{\text {post } 92}-w s h_{\text {pre } 92}=\frac{W_{b} N X K}{\left(W_{w} M+W_{b} N+X K\right)\left(W_{w} M+W_{b} N\right)}>0$.
} 
Observed wage inequality measured as ratio of white-collar to blue-collar wage rate in the pre-1992 regime also changes. Before 1992, it is:

$$
s k p r_{\text {pre92 }}=\frac{W_{w}}{W_{b}},
$$

and in the post-1992 regime it is:

$$
\text { skpr }_{\text {post } 92}=\frac{\frac{W_{w} M+X K}{M+K}}{W_{b}},
$$

where $\mathrm{J}$ is the number of partners who receive wages in the post-1992 period. In our data, partners and family members who begin to receive wages after the 1992 tax law change would get reclassified from being "unpaid proprietors or family members" to paid "white-collar workers". Therefore, measured wage inequality goes up if:

$$
\begin{aligned}
\text { skpr }_{\text {post } 92} & >s k p r_{\text {pre } 92} \\
\frac{W_{w} M+X K}{M+K} & >W_{w} \\
X & >W_{w} .
\end{aligned}
$$

Thus, if the amount of diverted profits per paid partner $(X)$ is higher than the mean whitecollar wage rate paid by the firm, we would expect measured wage inequality to go up for partnerships after the 1992 tax law changes.

To summarize, our model predicts the following for partnerships:

1. The white collar share of wages should rise following the 1992 tax law change.

2. Assuming that the diverted profits per paid partner is higher than white-collar wage rate, measured wage inequality (i.e., the skill premium) will go up. In our data, median wage per white-collar employee was only about INR 15,000 (about INR 32,250 at the 90th percentile), much lower than the measured profit before tax per unpaid partner of about INR 37,000 (about INR 329,150 at the 90th percentile). Thus, the assumption that the amount of transferred profits per partner was greater than wage rate for white-collar employees is likely to hold for most of the firms, and hence we expect mean wage inequality to increase for partnerships. ${ }^{26,27}$

Again, since the tax law changes were relevant only for partnerships, we expect the above predictions to hold only for this type of firm, and we expect no such changes to be observed for firms that have a different business form.

\subsection{Theories of Trade Liberalization and Inequality}

A number of studies have documented an increase in wage inequality following trade liberalization and the expansion of trade in many developing countries (see Kremer and Maskin, 2003, or

\footnotetext{
${ }^{26}$ Two factors reinforce this possibility. One, the ceiling on the optimal transfer (applicable for working partners with zero outside income) is INR 100,000, which is much higher than even the 90th percentile of observed mean white-collar wage rates. Two, profits per "working partner" would be even higher than the profits per partner calculated above, increasing the likelihood that profits transferred per working partner are greater than the observed white-collar wage rate.

${ }^{27}$ Another implication of the model is that the increase in white collar share of wages would be larger for smaller firms (or more precisely firms with lower number of white collar employees), since the ratio of diverted profits to white collar wage bill is likely to be higher for these firms. We tested this implication and found strong support for it in the data.
} 
Goldberg and Pavcnik, 2004, for an overview of this literature). We discuss briefly the main theoretical explanations for this link.

According to the simplest versions of the Heckscher-Ohlin model, developing countries should see a decrease in wage inequality following reforms. In this model developing countries do not have a comparative advantage in skill-intensive sectors, which would face import competition and which are protected prior to liberalization. Post-liberalization, according to the StolperSamuelson theorem that links product prices to wages, prices relatively decrease in the skillintensive import sector, which in turn reduces the wages of skilled workers. However, evidence suggests that unskill-intensive sectors are the ones that in fact receive the most protection. ${ }^{28}$ Thus, trade liberalization would lead to price drops in unskill-intensive sectors, leading to increases in skill premium consistent with the Stolper-Samuelson theorem.

An alternative argument for increasing wage inequality in developing countries following trade liberalization and the relaxation of foreign direct investment (FDI) regulations was proposed by Feenstra and Hanson (1996, 2003). They suggest that these reforms shift the production of intermediate goods from developed to developing countries. These products are skill-intensive from the point of view of developing countries (though relatively unskill-intensive from the point of view of developed countries, and hence outsourced to poorer countries). Thus, FDI generates demand for skilled workers. Another path through which FDI liberalization (coupled with reduction in tariffs and removal of other restrictions on import of capital) could affect skill premium is by increasing the use of capital; then if capital and skilled labor are complementary, this would lead to increased demand for skilled labor and hence an increase in the skill premium (Cragg and Epelbaum, 1996).

Another source of increases in skill premium could be skill-biased technological change, which could be induced by trade liberalization in three possible ways. Wood (1995) and Thoenig and Verdier (2003) suggest that intensified import competition leads to greater R\&D or adoption of technologies that would otherwise not have been adopted. These new technologies are generally skill-intensive, so that such skill-biased technological change leads to increases in skill premium. Acemoglu (2003) argues that tariff reductions lead to reduction in prices and hence increased imports of machinery, office equipment, and other capital goods that are complementary to skilled labor. Aghion, Burgess, Redding, and Zilibotti (2003) suggest that firms and sectors that are close to the technology frontier survive and thrive post-liberalization, but firms away from the technology frontier may be unable to fight external entry. These effects could lead to an overall increase in the skill premium, if the surviving domestic sector firms are close to the frontier and have higher skill-intensities.

In Verhoogen (2004), exporting requires high quality, which requires high-skill intensity. Trade liberalization offers export opportunities and thus increases demand for skilled workers, which leads to an increase in wage inequality.

\footnotetext{
${ }^{28}$ An earlier study (Sivadasan, 2005) shows that the largest tariff drops in Indian manufacturing were indeed in labor/lowskill intensive sectors. This somewhat anomalous protection of low-skill intensive sectors in developing countries has been documented by others (Goldberg and Pavcnik, 2004).
} 


\section{Data and Definition of Key Variables}

The primary data source for this study is the Annual Survey of Industries (ASI), undertaken by the Central Statistical Organization (CSO), a department in the Ministry of Statistics and Programme Implementation, Government of India. The ASI covers all industrial units, called "factories" (equivalent to plants) registered under the Factories Act employing more than 10 persons (if the plant used electricity) or 20 persons (for plants not using electricity). ${ }^{29}$ The ASI frame is classified into two sectors: the "census sector" and the "sample sector." Factories employing more than 100 workers constitute the census sector. Roughly one-third of the units in the "sample sector" are enumerated every year (changed from a sampling rate of one-half in 1987-88). Since unit-level data on electronic media have only recently become available to researchers, the unit-level ASI data is only beginning to be exploited in empirical studies (e.g., Sivadasan, 2005).

Certain limitations of the ASI data have been highlighted in the literature. Pradhan and Saluja (1998) conclude that the ASI provides "fairly reliable data" on organized manufacturing activity, but "with a considerable time-lag." Nagaraj (1999) highlights three other shortcomings of the ASI data: (1) incomplete coverage of factories, (2) underreporting of workers in factories covered, especially in small factories, and (3) underreporting of value added. He indicates that the underreporting may have increased over time. The questions we address are fortunately not significantly affected by these shortcomings in the data. The lag in reporting the data does not affect us as we are looking at historical data. The underreporting issues highlighted by Nagaraj do not bias our difference-in-differences estimates, under the reasonable assumption that the pattern of underreporting does not change differently across the liberalized versus the non-liberalized groups, or across one type of ownership group versus other types of ownership groups.

In addition to the ASI, we use various other sources of data on the Indian economy. We obtain information on tax rates for corporations and individuals from various volumes of the Statistical Abstract published annually by the Central Statistical Organization and from the website of the Income Tax Department in Delhi. ${ }^{30}$ Information on the sectors liberalized for FDI was obtained from the Handbook of Industrial Policy and Statistics issued by the Office of the Economic Advisor, Ministry of Industry, Government of India. Data on tariff rates were obtained from the World Bank Trade and Production database. Other data sources used include the annual Economic Surveys published by the Ministry of Finance, the Income Tax Act for various years from the website of the Central Board of Direct Taxes ${ }^{31}$ and data from various government websites. Information on partnerships and other legal entities were obtained from various commentaries on the website www.laws4india.com, including chapter 3 of Ramani et al.

(2004).

\footnotetext{
${ }^{29}$ Manufacturing activity undertaken in the informal sector (households (own-account) and unregistered workshops) are not covered by the ASI. Like other low-income countries, India had a large fraction of employment in the informal sector. According to estimates in Subrahmanya (2003), the employment share of the formal manufacturing sector was about 21.6 percent in $1989-$ 90. Figures from the Economic Census of 1991 suggest total employment in the manufacturing sector of about 30 million, which implies a share of the formal sector of about $27.5 \%$ (based on total employment in the ASI sector of about 8.2 million - see Table 2). Factories are analogous to plants, but are different from firms; multi-establishment firms would have multiple plants/factories.

${ }^{30} \mathrm{http}: / /$ incometaxdelhi.nic.in/taxsys/old.htm

${ }^{31}$ http://www.taxmann.com/TaxmannDit/DisplayPage/dpage1.aspx
} 
The ASI dataset and the data collected from other sources were collated and cross-indexed using different concordance tables. Indian data authorities use a National Industrial Classification (NIC) scheme that is close to the International Standard Industrial Classification (ISIC) scheme; we created a concordance between the NIC (1987 revision) and the ISIC (1997) by carefully comparing definitions of specific codes. The wholesale price index data is collated using another product classification scheme, and this was cross-indexed to the NIC (1987) revision by comparing individual categories under both the classification schemes. Many variables in the ASI dataset had to be standardized for consistency across the years. A detailed data appendix describing the ASI dataset and the various steps undertaken to clean the data is available on request from the authors.

We obtained unit-level ASI data for the nine-year period from 1986-87 to 1994-95 from the CSO. The data is reported on a financial year basis (e.g., the 1986-87 year refers to the period April 1, 1986 to March 31, 1987 - hereafter we refer to year 1986-87 as 1987 and so on.) There are about 50,000 plants in every year, yielding about 450,000 plant-year observations for the full dataset. For our analysis, we exclude extremely small plants (less than or equal to 5 employees), as the data on these plants appear to be noisy. ${ }^{32}$

The definitions of key wage and employment variables are explained in Table 1. Key points to note are that we have three broad categories of employees reported: (1) blue-collar/production workers (blue), (2) paid white-collar workers (white_paid), and (3) working proprietors and unpaid family members (prop). We define the white-collar wage rate as the total white-collar wage bill divided by the number of paid white-collar workers. The blue-collar wage rate is defined as total blue-collar wage bill divided by the number of blue-collar workers.

To analyze the effect of the tax law changes of 1992, we examine four variables:

1. "Fraction of non-salaried owners" is defined as "working proprietors and unpaid family members" (prop) divided by the total white-collar employment (white_paid + prop);

2. "Profits-to-sales ratio" are the profits before taxes (reported as "profits" in the dataset) divided by the "gross sales" (reported in the dataset);

3. "Wage-bill-to-sales ratio" is defined as the ratio of the total wage bill to "gross sales"; and

4. "White-collar wages-to-profits ratio" is defined as the ratio of the white collar wage bill to profits before taxes.

The total wage bill is equal to the sum of the blue-collar wage bill (bwbill) and the whitecollar wage bill (wwbill). ${ }^{33}$ We define two related measures of wage inequality: (1) the skill premium, which is defined as the ratio of blue-collar wage rate to white-collar wage rate, and (2) the white-collar share of the total wage bill.

The dataset is based on a survey of plants, while tax laws apply at the firm level. Because there could be many firms that have multiple plants within them, this raises two measurementrelated issues. The first issue is how profit is calculated at the plant level. Plant-level profits

\footnotetext{
32 This set of small plants constitutes about 3.75 percent of the manufacturing sector plants, but represents only 0.06 percent of total output, 0.19 percent of employment and about 0.91 percent of total capital. While the sampling frame for the survey is the register of plants that employ more than 10 employees, the actual dataset includes many firms with less than 10 employees. This arises because many plants get registered even if they employ less than 10 people, even though they are required to register only if they exceed the 10-person limit. Also once the plant is registered, it would continue to be in the sampling frame even after the employment levels dropped below the 10-person threshold.

${ }^{33}$ Refer to Table 1 for definitions of the wage bill variables bwbill and wwbill.
} 
in our dataset are calculated based on subtracting from reported gross sales the materials costs, total wage bill, interest expenses, total rent, and depreciation. This reported profit could be a noisy indicator of the firm-level taxable profits for two reasons. First, for multi-plant firms, profits at the firm level would be an aggregate of plant-level profits, and if the profitability of different plants are not perfectly correlated, regressions using plant-level data could yield different results from using plant-level data. Secondly, for both multi- and single-plant firms, profits reported here are based on accounting numbers for sales, material expenses, and depreciation that could differ from the firm-level taxable profits for various reasons (for example, depreciation rates under tax laws differing from those used under Indian accounting standards). We expect these measurement issues to be stable over time, and have no reason to expect the resulting measurement error to systematically upward bias our estimates of the tax law change. ${ }^{34}$

The second issue with using plant-level data is whether the estimates of income shifting and measured wage inequality effects predicted at the firm level would be biased (upwards or downwards) when looking at plant-level data. Because the incentives to shift income from profits to wages should apply to all the establishments within the firm, we expect the shift to show up in the plant-level data too. Again, we do not expect measurement errors from aggregation and differences between tax and accounting data to systematically bias our results upward. ${ }^{35}$

\section{Empirical Evidence on Direct Effects of 1992 Tax Law Change}

Here we present results from examining the behavioral implications of the tax law change, on four variables: (1) unpaid owners as fraction of white-collar employment; (2) profits-to-sales ratio, (3) total wage-bill-to-sales ratio, and (4) the white-collar wage-bill-to-profits ratio.

\subsection{Trends}

In figure 1, we present trends in the ratio of unpaid owners to white-collar employment for different types of business forms. As predicted by the model, the ratio of unpaid owners to white-collar employees falls sharply for partnerships after 1992. Significantly, there are no such effects for other categories of firms. Also note that unpaid owners are a much larger fraction of white-collar employment in sole proprietorships and partnerships compared to other business forms, as may be expected due to their generally smaller size.

Figure 2a shows the trends in the ratio of profits-to-sales for partnerships. The ratio of profits-to-sales goes down in 1993 for partnerships. In figure 2b, we find that the ratio of total wages-to-sales goes up for partnerships following the tax law change. In figure 3 , we see that the ratio of white-collar wage-to-profits goes up significantly beginning in 1993.

All of these results are consistent with our model's predictions about the impact of the tax law change that allowed wage payments to partners to be deducted from the partnership firm's

\footnotetext{
${ }^{34}$ In fact classical measurement error in the variables could bias our estimates downward. The problem of aggregation may be less severe for partnership firms, as they are generally smaller and hence more likely to be single-plant firms.

${ }^{35}$ For multi-establishment firms where different establishments belong to different industries, the industry classification of the headquarters firm may be imprecise. Parameters identified by looking at differences across industries could be biased by this misclassification. We do not expect this measurement error to systematically bias our results, as our primary results are based on differences within industries (i.e., we include industry-location fixed effects).
} 
taxable income beginning in 1993, prompting partners to begin paying themselves wages. This moves some amounts from profits to the white-collar wage bill in our data. This shifting of income from profits to partners' wage payments results in the changes observed in figures 1, 2a, $2 \mathrm{~b}$, and 3 .

Note that in all our figures we examine trends in medians rather than means because the mean value of these variables are skewed; since all of them are ratios, true or measurement error that causes denominators close to zero give rise to extreme outliers which severely skew the mean.

In the next section, we examine regression specifications that allow us to examine the size and statistical significance of the effects observed in these figures controlling for different factors.

\subsection{Regression Results}

Table 4 presents the results of a series of multivariate regression analyses of the four indicators of tax-induced income shifting. The specifications include various fixed effects, including year effects, to control for possible omitted variables. All dependent variables are winsorized by 2 percent on both ends of the distribution, to prevent outliers from skewing the mean effects.

In the first specification, we identify the effect of the tax law change, as the difference-indifferences effect on partnerships of the tax change, captured as year dummies for 1993, 1994, and 1995 (1987 is the omitted year in these specifications). Inclusion of year effects implies that the coefficient on the interaction between the period dummy and the partnership dummy captures the difference-in-differences effect of the reform on partnerships relative to all non-partnership businesses. We include state-industry-size dummy variables to control for unchanging locationindustry-size effects.

In the second specification for each of the four indicators, we control for common stateindustry-size-year shocks; thus, if the effects in the first regression are driven by peculiar shocks in the post 1992 period to certain size categories (defined using size quartile dummy variables) of firms and/or locations and/or industries, which are correlated with the partnership dummy (for example, if partnerships are disproportionately concentrated in some location or industry which receives some external shock, or if smaller sized firms received a certain type of shock), this specification would control for those shocks.

We find that, in both the specifications and for all four variables of interest, there is a large and significant difference-in-differences effect of the Finance Act of 1992 on income shifting in partnerships. We find a 10 to 14 percent decline in fraction of non-salaried owners among partnerships immediately following the tax law change, relative other firms in the same stateindustry cell. Similarly, we find a 2.2 percent to 3.3 percent decline in the profits-to-sales ratio. The wage-bill-to-sales ratio goes up in the post-tax change period (by about 2.5 percent to 2.9 percent), while the ratio of the white-collar wage-bill-to-profits goes up significantly, by between 31 percent and 47 percent, in the post-reform period. All these effects are significant at the 1 percent level. These regressions thus confirm the impression from the graphs that 1993 marks a sharp divergence in behavior between partnerships and other businesses not affected by the Finance Act of 1992 .

For the profits-to-sales and the wages-to-sales ratios, there is some upward trend in the 
variables prior to the reform period. The relative effects are the starkest for the fraction of unsalaried owners and for the ratio of white-collar wage-bill-to-profits. For the latter two variables, there are no economically or statistically significant changes in the years before the tax law change; in contrast there are large and statistically significant effects in the years after the tax law change. Because there are no large changes in the coefficients between specifications 1 and 2 , we can conclude that these estimates are not driven by state-industry time shocks coincident with the tax law change. Finally, note that the pattern of the estimated coefficients (especially for the two variables where the tax law effect is the strongest) suggests that the biggest change occurred in the year 1993 (the year the tax law change came into force); this suggests that there was relatively rapid learning about the implications of the law. ${ }^{36} 37$

\section{Empirical Analysis of Wage Inequality Measures}

\subsection{Trends}

Because the tax change of 1992 followed closely on the heels of the liberalization initiatives of 1991, the impact of the former on income shifting between profits and white-collar wages could affect the analysis and conclusions about the implications of the latter. To begin to address this issue, first look at figure 4, which presents trends in different percentiles of the distribution of the log wage inequality (skill premium) over the years, and figure 5, which presents different percentiles of the white-collar share of the wage bill. Both figures are for the full sample of firms in the dataset. As is evident from the graphs, both the skill premium and the white-collar share of the wage bill show a significant increase (across different percentiles), but the sharp increase begins in the year 1993 (which corresponds to fiscal year 1992-93), the first year for which the new tax provisions became effective.

In figures 6 and 7, we examine the trends in the mean of the two wage inequality measures for different business forms. It is evident that there was a big increase in the mean log skill premium for partnerships beginning in 1993. Strikingly, the magnitude of this jump is much higher than the changes experienced by any other type of business. (There is some increase in skill premium for public-limited companies, but the magnitude is much smaller than the jump for partnerships.) Similarly, in figure 6, we find a jump starting in 1993 in the white-collar share of wages, which is again much more striking for partnerships.

\footnotetext{
${ }^{36}$ We also ran this analysis separately for rural and urban firms to test whether urban firms which may have better access to tax specialists/accountants were quicker in responding to the law change. The results suggest a slightly faster response rate in urban locations (the coefficients in the urban-only regression are somewhat bigger than that for the full sample). Regarding the fraction of non-salaried owners, the response of urban partnerships was quicker and larger than rural partnerships; similarly, the effects are stronger for urban partnerships with regard to the white-collar wage-bill-to-profits ratio. The differences are not stark for the other two variables (profits-to-sales and wages-to-sales ratio). We conclude that learning about the tax law change was quite rapid in both urban and rural locations.

${ }^{37}$ It may be possible that some establishments that paid above-average skill premia switched from the informal sector to "registered partnerships" status in the formal sector around the time of the tax law change, driven by other macro-economic changes in the economy. To test this, we also ran the analysis separately for old and young firms, where "old" is defined as establishments that were at least 10-years old, thus restricting the sample to establishments that entered well before the tax law change was introduced. We find some evidence of a slightly larger response by older partnerships with respect to the fraction of unpaid owners and the white-collar wage-to-profit ratio. The differences are less striking for the other two variables of interest, with weak evidence for a slightly faster and larger response by older partnerships. These tests show that the effects for the full sample were not driven by differential responses from establishments that entered (or exited) after the tax law change was introduced. This conclusion is supported by an analysis using a balanced panel data sub-sample, where we found significant responses to the tax law change by already existing partnership firms. Also, as discussed earlier, we find no significant change in the distribution of ownership forms. (There is a downward trend over the whole period in the fraction of firms that are partnerships, but no change in this trend around the time of the tax reform.)
} 
These figures are consistent with the model predictions (assuming that the partnerships transferred surplus per partner greater than then pre-1993 average white-collar wage). Taken together with the results in Section 5 above, these graphs suggest that partnerships shifted income from profits to wages, and that this change had a significant effect on the observed overall average trends in skill premium.

Note that the overall mean for the population is heavily affected by the changes for partnerships. Since partnerships constitute 50 percent of the total number of firms (see Table 2), the overall population mean is impacted equivalent to half the magnitude of the mean effect on partnerships. From Table 2, we can see that the impact of partnerships would be somewhat reduced (but would still be significant) if we look at employment-weighted aggregate means of skill premiums and white-collar wage bill shares.

\subsection{Regression Results: Baseline Specifications}

Next, we investigate this issue more closely by performing a series of regression analyses of the observed trends in log skill premium and skill intensity (white-collar share of wages). We regress these measures on time dummies, controlling for state-industry-size fixed effects (i.e., we define cells by state, industry, and size, and include dummies to capture fixed effects for each cell). We also include interactions of the time dummies with a dummy for partnerships.

The results are presented in Table 5a. In columns 1 and 3 the independent variables are year dummies; the omitted year is 1987. In columns 2 and 4, we summarize the trends using period dummies - period 0 (which is omitted in the regressions) refers to years 1987, 1988, 1989, and 1990; period 1 refers to the transition period of 1991 and 1992, and period 2 refers to the period after the tax law change (1993, 1994, and 1995).

In columns 1, 2, 3 and 4, we examine the log skill premium (ratio of white-collar to blue-collar wage rates). We find that almost all of the observed increase in the mean log skill premium can be attributed to changes made by partnerships. All the year coefficients after the 1992 tax law change (1993, 1994, and 1995 year dummies) lose statistical and economic significance, once we control for changes made by partnerships. The year effects are summarized in the regressions with period dummies (column 2 and 4). We see that there was approximately a 7.6 percent increase in the skill premium ${ }^{38}$ in the period after the tax law change. However, once we control for actions taken by partnerships, this effect completely disappears. Thus all of the post taxchange increase in wage inequality could be attributed to changes made by partnerships. We argue that for partnerships, these changes reflect the tax-induced income shifting rather than liberalization-induced real effects in skill premia.

In columns 5, 6, 7, and 8, we examine the white-collar share of labor (scaled by 100, so it is expressed in percentage terms). We find that there is an increase in the mean white-collar share of wages of about 4.6 percentage points (coefficient on dummy for period 2) following the tax law change (from about 26.7 percent in the pre-1991 period to about 31.3 percent). We find that the coefficient on period 2 drops to 1.08 percent after we control for changes in partnerships; thus about 77 percent of the increase (3.55 percent out of 4.63 percent) in the mean white-collar

\footnotetext{
${ }^{38}$ Expressing changes in logged skill premium as percentage changes. This is only approximate, and is more exact for small log point changes; the actual percentage change would be larger when the log point changes are large.
} 
share of wages can be attributed to changes made by partnerships, which reflect income shifting due to the 1992 tax law change.

The results of regressing the log skill premium and the white- collar share of wages on year dummies are summarized in figures 7 and 8 respectively. As can be seen in the figure, the big jump in the mean skill premium and white-collar share of wages in 1993 disappears when we control for the 1992 tax change (by conditioning out the actions of partnerships). Thus the big jump in 1993 appears driven by the tax law change.

\subsection{Regression Results: Robustness to Trade Liberalization-related Causes}

Because the jump in skill premium and white-collar share of labor is observed some months after major reforms to trade and investment regulations were announced in July 1991, we should consider a number of plausible alternative explanations for the observed trends, based on the various theoretical explanations proposed for increases in skill premium following trade liberalization discussed in Section 3.2.

In Section 6.2, to identify the effects of the tax change, we attributed the behavior of partnerships (relative to other types of corporate entities) as being driven by the tax law change that affected only partnership firms. This difference-in-differences strategy controls for the pervasive effect of the number of different reforms introduced in 1991. To the extent that the market for skilled labor is common across different types of firms within and/or across industries, common year effects would control for the effect of trade liberalization related causes of increases in skill premium.

However, the difference-in-differences identifying strategy could fail, if it was the case that some other change was driving the behavior of a certain groups of firms (say in certain industries) and partnerships happened to be concentrated among those firms (or those industries). For example, the market for skilled labor may be segmented, so that the various trade-related causes of increased demand for skilled labor affects certain industries more than others, and partnerships may be disproportionately concentrated in some of the most affected industries. To control for this, in Tables $5 \mathrm{~b}$ and $5 \mathrm{c}$, we include additional controls for dynamic effects on specific industries and/or firms.

The first alternative story we examine is the reduction in tariff rates. ${ }^{39}$ As discussed in Section 3.2, Stolper-Samuelson effects could drive the skill premium and share of white-collar wages up in tariff liberalized industries. There was a significant reduction in tariff rates in India in 1991. So in column 3 of Table $5 \mathrm{a}$ and $5 \mathrm{~b}$, we include a variable that measures the drop in tariff between 1990 and 1992 at the 3-digit industry level ("Tariff drop (1990-92)"), as well as this variable interacted with period dummies. If the skill premium increased in the post-1991 period in industries where tariffs were reduced, then this tariff drop variable interacted with the post-1992 period dummy would pick up the effect (and the coefficient on the post-1992 dummy would fall).

Next, we consider the trade orientation of the industry. We use two measures - export ori-

\footnotetext{
${ }^{39}$ As mentioned above, each of these alternative controls are required only if the markets for skilled labor are segmented, so that increases in skill premia are concentrated in certain industries. Dissipated effects are captured by the year effects in Table 5 a.
} 
entation, measured as the mean ratio of exports to output by industry for the pre-1991 period ("Exports to output ratio (pre-91)"); and import orientation, measured as the mean ratio of imports to output by industry for the pre-1991 period ("Imports to output ratio (pre-91)"). If the Thoenig-Verdier (2003) or Wood (1995) type argument is true, we could expect the largest increases in skill premium to be concentrated among import-competing industries. If the Verhoogen (2004) explanation is true, we would expect the largest increases in skill premia in the export-oriented sectors. Third, we consider liberalization of FDI, measured as a dummy variable equal to one for industries that were opened to majority foreign direct investment in 1991 ("FDI deregulation dummy"). If the Feenstra-Hansen (1997, 2003) argument holds, we could expect the strongest effect in the industries for which FDI was liberalized. Fourth, we include a control for the capital intensity - the log of the ratio of real capital to real value added for each establishment ("Capital-output ratio"). If trade liberalization increases demand for capital and if skill is complementary to capital, we should see increases in the skill-premium and white collar share of wages driven by capital deepening. Finally, to address the explanation offered by Aghion et al. (2003), we include distance to the frontier, measured as the ratio of maximum (over all 4-digit industries) industry mean log total factor productivity to the industry mean total factor productivity ("Distance to frontier").

Our results in Table 5b show that none of the trade-related explanations reduce the significance of the effect of partnerships on log skill premium. Distance to the frontier is weakly significant by itself, but loses significance when all other controls including the partnership dummy are included. ${ }^{40}$ The inclusion of all the other controls has very little effect on the partnership dummy, and explains very little of the post-1992 jump in log skill premium. Similar results are obtained for the white-collar share of wages in Table 5b. The one exception is that the capital output ratio appears to be important, both by itself (column 7) and with other controls (column 9). Also, the combined regression (column 9) explains about half of the remaining increase in white-collar share of wages in the post-1992 period (1.083 percent drops to 0.53 percent). This suggests that, consistent with arguments made by Cragg and Epelbaum (1996) and Behrman, Birdsall, and Szekely (2000), increases in capital intensity (as well as the increased skill premium for capital intensive firms), play a significant role in explaining the patterns in the white-collar share of wages. Again, distance to the frontier is significant by itself, but drops in significance once other controls are included. The coefficient on partnership dummy drops very slightly in the combined regression (column 9).

Overall we interpret our results as strong evidence that the observed increase in the measured log skill premium and the white-collar share of wages were driven primarily by the income shifting behavior of partnerships following the tax changes of 1992, even controlling for the effects of trade liberalization, trade orientation interacted with liberalization (through period dummies), FDI liberalization, capital deepening, and distance to the frontier.

\section{Conclusions}

In 1992, India changed its income tax law in a way that provided partnerships incentives to shift income from profits to wages. We find in the data that there was a strong response to these

40 This would be consistent with partnership firms being concentrated in industries further from the frontier, as defined here. 
incentives. The fraction of non-salaried owners, profits-to-sales ratio, the wage-to-sales ratio, and the white-collar wage-to-profits ratio, all change as predicted by economic theory. Crucially, because the tax law change affected only partnerships, we are able to identify the effects of the tax law change by comparing outcomes for partnerships relative to other business entities. The data allow us to control for a variety of fixed effects, and also for industry-size-location specific time-varying shocks that could affect the variables of interest. ${ }^{41}$ Our results show that firms respond strongly to tax incentives for income shifting in a developing country context, suggesting that tax policy interventions can be effective in modifying firm behavior.

The income shifting behavior has important implications for some widely-used measures of wage inequality. This is especially important because the tax law change followed by just one year a major trade and market liberalization that might by itself have caused shifts in the skill premium, and thus wage inequality. We find that, without controlling for the tax law change, there is an increase in the mean skill premium of about 7.3 percentage points (significant at the 1 percent level) in the post-1992 period compared to the pre-1991 period. Similarly, there is an increase in the mean white-collar share of the wage bill of 4.6 percentage points (significant at the 1 percent level). However, once we condition out the effect of the taxes (by conditioning out responses by partnership firms), we find only a 0.8 percent point increase in the log skill premium, and a 1.1 percent increase in the white-collar share of the wage bill. Our analysis thus suggests that the major Indian trade and market liberalization measures announced in 1991 did not have a large effect on wage inequality in the Indian manufacturing sector, at least in the four years following the liberalization.

One should exercise caution in applying these findings to the important question of how the market reforms affected overall income inequality and poverty in India. First, our study focuses on the wage inequality and skill premium in the registered manufacturing sector only. We are hesitant about generalizing these results to the entire economy, as the registered manufacturing sector comprises a small part of the total economically active population. ${ }^{42}$ Also, note that increasing wage inequality is not the same as increasing poverty; for example, an increase in the wage rate for skilled labor could increase inequality without increasing poverty. ${ }^{43}$ Given the large population of extremely poor people and the importance of poverty reduction as a policy goal,

\footnotetext{
${ }^{41}$ In our model and analysis, we examine the incentives for avoiding taxes by shifting of income from profits to wages provided by the 1992 tax law change. In addition to the legitimate shifting of income from profits to wages, some firms may try to evade entity-level taxes by underreporting sales. Our checks indicate that there was no significant change in log gross sales around the time of the 1992 tax reform for partnership firms relative to other firms within the same industry-state cells. (There is a downward trend in the mean log gross sales for partnership firms but, unlike for the income shifting related variables, there is no change in this trend around 1992-93.) Other ways to evade taxes may be to report additional employees, or reduce value added by inflating material costs. We found no significant change for partnerships in either total employment or log value added. Thus we do not find evidence for illegal tax evasion responses at the time of the tax change we are studying.

${ }^{42}$ Figures from the ILO (http://laborsta.ilo.org/) indicate a total economically active population (age 15 years and above) of about 302 million in 1991. Our dataset covers about 8 million employees (see Table 2). The small proportion is not surprising considering the large share of agriculture (about 65\%, according to ILO figures) and the large share of informal manufacturing (about 72 to $78 \%$ of employment in the manufacturing sector - see footnote 29 ).

43 Banerjee and Piketty (2005) examine inequality by looking at the share of total taxable income received by the top 1 percent of the taxpayers and find an increase in such inequality in the 1990s. They find a larger growth in wage compared to non-wage income during the 1990s. Using their data, we find a temporary increase in ratio of wage to non-wage income around the time of the tax law change. While these results are not inconsistent with our findings, closer comparisons are difficult given the differing nature of the two data sources. Trends in wage and overall inequality could diverge if there is rapid growth in non-wage income due to outside factors (such as the rapid economic growth in the 1990s). In addition, trends in the distribution of sources of taxable income could be affected by changes in the quality of tax enforcement technology for non-wage income relative to wage income (as discussed in Banerjee and Piketty, 2005, a number of innovations in tax collection were introduced in the 1990s).
} 
an extensive literature has examined whether poverty reduction has accelerated or decelerated after the reforms introduced in the early 1990s. This literature is intensely divided, with "no consensus on what happened to Indian poverty in the 1990s" (Deaton and Kozel, 2005). Since most of these studies are based on household expenditure surveys, they are unlikely to be affected by the measurement bias induced by tax-driven income-shifting observed in our manufacturing plants survey dataset.

Our findings provide evidence for rapid and large responses by business entities and their principals to income shifting incentives provided by tax law changes, and is one of the first to provide systematic evidence of this in a developing country context. As suggested by Slemrod (1990), income shifting is particularly responsive to tax incentives. While this paper documents an episode of substantial income shifting, it also demonstrates the danger of drawing welfare conclusions based on estimated elasticities of a narrowly defined tax base with respect to the tax rate applied to that base. In this case, the elasticity of reported wages to the tax rate on wage income overstates the efficiency cost, per dollar raised, of taxing wage income, because some of the response represents a shift to (taxed) partnership income. Slemrod (1998) elaborates on this issue.

The results discussed here also suggest that tax law changes could have important consequences for studies of wage inequality that rely on data that could be polluted by tax-induced income-shifting behavior, as have a number of studies of wage inequality that have used manufacturing sector survey datasets similar to ours. As demonstrated in our study, income shifting from profits to wages (or vice versa) could significantly bias measured wage inequality in these types of datasets. ${ }^{44}$

Finally, our study provides a cautionary tale with regard to event studies that use a beforeand-after approach to identify the effect of government policy changes or other events. For example, a number of studies, especially the early studies of trade liberalization, used the beforeand-after approach to identify the effects of liberalization on productivity and wage inequality. ${ }^{45}$ Other tax or regulatory changes coincident with the event being studied could significantly affect an accurate interpretation of the investigation, unless strategies are adopted to control for these other changes.

\section{References}

[1] Acemoglu, Daron. 2003. "Patterns of Skill Premia." Review of Economic Studies 70 (2): 199-230.

[2] Acharya, Shankar. 2002. "India: Crisis, Reforms and Growth in the Nineties." Stanford University Working Paper No. 139. Stanford: Center for Research on Economic Development and Policy Reform.

\footnotetext{
${ }^{44}$ Note that studies of income inequality that use data on total income may be less susceptible to biases due to income shifting induced by tax law changes. However, even income inequality studies using individual household survey data could be biased due to misreporting for two reasons. First, different sources of income, such as wages versus partnership income, may be reported with different degrees of reliability. Second, in our context, anecdotal evidence and tax notifications suggest that profits accruing to individual partners were not being reported to tax authorities; it is thus likely that this income would not be reported in household surveys, either.

${ }^{45}$ See the reviews by Tybout (2001) or Epifani (2003). More recent work on trade liberalization using difference-in-differences approaches may be less prone to this problem.
} 
[3] Aghion, Philippe, Robin Burgess, Stephen Redding, and Fabrizio Zilibotti. 2003. "The Unequal Effects of Liberalization: Theory and Evidence from India." Mimeo. London School of Economics, London.

[4] Banerjee, Abhijit, and Thomas Piketty. 2005. "Top Indian Incomes, 1922-2000." The Word Bank Economic Review 19 (1): 1-20.

[5] Behrman, Jere, Nancy Birdsall, and Miguel Szekely. 2000. "Economic Reform and Wage Differentials in Latin America." IADB Working Paper No. 435. Washington, D.C.: InterAmerican Development Bank.

[6] Benami Transactions (Prohibition) Act No. 45. 1988. Enacted by Parliament in the Thirty-ninth Year of the Republic of India (accessed at http://www.vakilno1.com/bareacts/Benamiact/benami.htm February 2006).

[7] Berman, Eli, John Bound, and Zvi Griliches. 1994. "Changes in the Demand for Skilled Labor within U.S. Manufacturing: Evidence from the Annual Survey of Manufacturers." The Quarterly Journal of Economics 109 (2): 367-97.

[8] Cragg, Michael I., and Mario Epelbaum. 1996. "Why Has Wage Dispersion Grown in Mexico? Is It the Incidence of Reforms or the Growing Demand for Skills?" Journal of Development Economics 51 (1): 99-116.

[9] Deaton, Angus, and Valerie Kozel. 2005. "Data and Dogma: The Great Indian Poverty Debate." Princeton University Working Paper. Princeton: Research Program in Development Studies.

[10] DeLong, J. Bradford. 2001. "India Since Independence: An Analytic Growth Narrative." University of California Working Paper. Berkeley: University of California.

[11] Epifani, Paulo. 2003. "Trade Liberalization, Firm Performance and Labor Market Outcomes in the Developing World: What Can We Learn from Micro-Level Data?" University of Parma and CSPRI-Bocconi University Working Paper. Parma: University of Parma and Bocconi: CSPRI-Bocconi University.

[12] Feenstra, Robert C., and Gordon Hanson. 1996. "Foreign Investment, Outsourcing and Relative Wages." In Political Economy of Trade Policy: Essays in Honor of Jagdish Bhagwati, edited by Robert C. Feenstra, Gene M. Grossman, and Douglas A. Irwin, 89-127. Cambridge, MA: MIT Press.

[13] Feenstra, Robert C., and Gordon Hanson. 1997. "Foreign Direct Investment and Relative Wages: Evidence from Mexico's Maquiladoras." Journal of International Economics 42 (3-4): $371-93$.

[14] Feenstra, Robert C., and Gordon Hanson. 2003. "Global Production Sharing and Rising Inequality: A Survey of Trade and Wages." In Handbook of International Trade, edited by E. Kwan Choi and James Harrigan, 146-85. Malden, MA: Blackwell.

[15] Goldberg, Pinelopi Koujianou, and Nina Pavcnik. 2004. "Trade, Inequality, and Poverty: What Do We Know? Evidence from Recent Trade Liberalization Episodes in Developing Countries." NBER Working Paper No. 10593. Cambridge, MA: National Bureau of Economic Research (accessed at http://www.nber.org/papers/w10593).

[16] Gordon, Roger H., and Joel Slemrod. 2000. "Are 'Real' Responses to Taxes Simply Income Shifting Between Corporate and Personal Tax Bases?" In Does Atlas Shrug?.. The Economic Consequences of Taxing the Rich, edited by Joel Slemrod. New York: Russell Sage Foundation and Cambridge, MA: Harvard University Press.

[17] Hanson, Gordon H., and Anne Harrison. 1999. "Trade Liberalization and Wage Inequality in Mexico." Industrial and Labor Relations Review 52 (2): 271-88. 
[18] Income Tax Act, 1961 (as amended by the Finance Act 1992 accessed at http://www.taxmann.com/TaxmannDit/DisplayPage/dpage1.aspx ).

[19] Kremer, Michael, and Eric Maskin. 2003. "Globalization and Inequality." Harvard University Working Paper. Cambridge, MA: Harvard University.

[20] MacKie-Mason, Jeffrey, and Roger Gordon. 1997. "How Much Do Taxes Discourage Incorporation?" Journal of Finance 52 (2): 477-505.

[21] Nagaraj, R. 1999. "How Good Are India's Industrial Statistics? An Exploratory Note." Economic and Political Weekly 34 (6): February 6-12.

[22] Pavcnik, Nina. 2003. "What Explains Skill Upgrading in Less Developed Countries?" Journal of Development Economics 71 (2): 311-28.

[23] Pradhan, Basanta K., and M. R. Saluja. 1998. "Industrial Statistics in India: Sources, Limitations and Data Gaps." Economic and Political Weekly 33 (21): May 23-29.

[24] Ramani, K. K., N. C. Jain, Sunil K. Ramani, K. R. Lakshminarayanan, and Pritesh Mehta. 2004. Doing Business in India (accessed at http://www.laws4india.com/nrilaws/dbi/dbi_homepage.asp).

[25] Revenga, Ana. 1997. "Employment and Wage Effects of Trade Liberalization: The Case of Mexican Manufacturing." Journal of Labor Economics 15 (3): S20-S43.

[26] Sivadasan, Jagadeesh. 2005. "Productivity Consequences of Foreign Direct Investment and Trade Liberalization: Micro-evidence from Indian Manufacturing Sector Reforms." Working Paper. Ann Arbor, MI: University of Michigan.

[27] Slemrod, Joel. 1990. "The Economic Impact of the Tax Reform Act of 1986." In Do Taxes Matter? The Impact of the Tax Reform Act of 1986 edited by Joel Slemrod. Cambridge, MA MIT Press.

[28] Slemrod, Joel. 1998. "Methodological issues in Measuring and Interpreting Taxable Income Elastcities." National Tax Journal, December, 51(4), pp. 773-788.

[29] Subrahmanya, M. H. Bala. 2003. "Unorganized Manufacturing Industry in India: Its Changing Role and Declining Significance during Industrial Liberalization." Indian Institute of Science Working Paper. Bangalore: Department of Management Studies.

[30] Tax Reform Committee. 1991. Interim Report. New Delhi: Government of India, Ministry of Finance (Department of Revenue).

[31] Thoenig, Matthias and Thierry Verdier. 2003. "A Theory of Defensive Skill-based Innovation and Globalization." American Economic Review 93 (3): 709-2

[32] Tybout, James R. 2001. "Plant- and Firm-Level Evidence on 'New' Trade Theories." Pennsylvania State University Working Paper. University Park: Pennsylvania State University.

[33] Verhoogen, Eric. 2004. "Trade, Quality upgrading and Wage Inequality in the Mexican Manufacturing Sector: Theory and Evidence from an Exchange-Rate Shock." Mimeo, University of California, Berkeley.

[34] Wood, Adrian. 1995. "How Trade Hurt Unskilled Workers." Journal of Economic Perspectives 9 (3): $57-80$. 
Appendix 1: Restrictions on deductible remuneration to partners in the Finance Act, 1992 $^{46}$

The amount of remuneration paid to "working partners" that is deductible while calculating the partnership firm's taxable profits is limited to:

(a) on the first Rs. 75,000 of the book-profit, or in case of a loss

(b) on the next Rs. 75,000 of the book-profit

(c) on the balance of the book-profit
Rs. 50,000 or at the rate of 90 percent of the book-profit, whichever is more;

at the rate of 60 percent;

at the rate of 40 percent

\footnotetext{
${ }^{46}$ Extract from Section 40(b) of the Income Tax Act, 1961, after amendments introduced by the Finance Act, 1992.
} 
Table 1: Definition of employment and wage variables (traced to primary variables in the data) (See data appendix for definitions of other variables.)

\begin{tabular}{|c|c|c|c|}
\hline Variable & Label & Definition & Source \\
\hline \multicolumn{4}{|c|}{ Employment variables } \\
\hline totwrkrs & Workers (nos.) & $\begin{array}{l}\text { Equivalent to blue-collar/ } \\
\text { production workers }\end{array}$ & In data \\
\hline totemp & All employees (nos.) & $\begin{array}{l}=\text { totwrkrs }+ \text { supervisory and } \\
\text { managerial staff }+ \text { other } \\
\text { employees }\end{array}$ & In data \\
\hline totpersons & Total persons engaged & $\begin{array}{l}=\text { totemp }+ \text { working proprietors } \\
+ \text { unpaid family members }\end{array}$ & In data \\
\hline blue & Number of blue-collar workers & $=$ totwrks & Defined \\
\hline white & Number of white-collar workers & $=$ totpers - totwrkr & Defined \\
\hline prop & $\begin{array}{l}\text { Number of proprietors \& family } \\
\text { members }\end{array}$ & $=$ totpers - totemp & Defined \\
\hline white_paid & Paid white-collar employees & $=$ white - prop $^{1}$ & Defined \\
\hline \multicolumn{4}{|c|}{ Wage variables } \\
\hline wages & Wages to workers & $=$ wages to blue-collar workers & In data \\
\hline salaries & Salaries to employees & $\begin{array}{l}=\text { wages to blue-collar plus } \\
\text { wages to white-collar }\end{array}$ & In data \\
\hline bwage & Blue-collar wages & $=$ wages & Defined \\
\hline wwage & White-collar wages & $=$ salaries-wages & Defined \\
\hline bonuswrkrs & Bonus paid to workers & $=$ bonus to blue & In data \\
\hline bonusemp & Bonus to employees & $=$ bonus to blue + white & In data \\
\hline bbon & Blue-collar bonus & $=$ bonuswrkrs & Defined \\
\hline wbon & White-collar bonus & =bonusemp-bonuswrkrs & Defined \\
\hline wemol & White-collar emol. (wages + bonuses) & $=$ wwage + wbon & Defined \\
\hline bemol & Blue-collar emol. (wages + bonuses) & $=$ bwage+bbon & Defined \\
\hline totben & Total value of benefits to all empl. & $\begin{array}{l}=\text { contribution to PF + welfare } \\
\text { expenses }\end{array}$ & In data ${ }^{2}$ \\
\hline wben & White-collar benefits & $=$ totben*wemol $/($ wemol+bemol $)$ & Defined \\
\hline bben & Blue-collar benefits & $=$ totben ${ }^{*}$ bemol $/($ wemol+bemol $)$ & Defined \\
\hline bwbill & Total blue-collar wage bill & $=$ wemol + wben & Defined \\
\hline wwbill & Total white-collar wage bill & $=$ bemol + bben & Defined \\
\hline \multicolumn{4}{|c|}{ Wage rates, skill premium, and white-collar share of wage bill } \\
\hline bwrate & Blue-collar wage rate & $=$ bwbill $/$ blue & Defined \\
\hline wwrate & White-collar wage rate & $=$ wwbill $/$ white_paid & Defined \\
\hline skprem & Skill premium & $=$ wwrate $/$ bwrate & Defined \\
\hline wshare & White-collar share of wage bill & $=$ wwbill $/($ wwbill + bwbill $)$ & Defined $^{3}$ \\
\hline log_skpr & Log (skill premium) & $=\log ($ skprem $)$ & Defined \\
\hline log_wsh & Log(white-collar share of wage bill) & $=\log ($ wshare $)$ & Defined \\
\hline
\end{tabular}


Table 2: Different types of business entities in the Indian manufacturing sector for a single cross-section (year 1991, adjusted for sampling weights)

\begin{tabular}{|c|c|c|c|c|}
\hline Corporate Type & $\begin{array}{c}\text { Number of } \\
\text { Plants }\end{array}$ & $\begin{array}{c}\begin{array}{c}\text { Fraction } \\
\text { (number) }\end{array} \\
\end{array}$ & $\begin{array}{c}\text { Total } \\
\text { Employment } \\
\end{array}$ & $\begin{array}{c}\text { Fraction } \\
\text { (Employment) }\end{array}$ \\
\hline Partnership: Joint family & 6,962 & $7.6 \%$ & 202,429 & $2.5 \%$ \\
\hline Partnership: Other & 39,016 & $42.4 \%$ & $1,383,364$ & $16.8 \%$ \\
\hline Partnerships: Total & 45,978 & $50.0 \%$ & $1,585,793$ & $19.3 \%$ \\
\hline Private-limited company & 16,035 & $17.4 \%$ & $1,099,042$ & $13.4 \%$ \\
\hline Public-limited company & 7,678 & $8.4 \%$ & $3,091,401$ & $37.6 \%$ \\
\hline Companies: Total & 23,713 & $25.8 \%$ & $4,190,443$ & $50.9 \%$ \\
\hline Individual proprietorship & 16,027 & $17.4 \%$ & 404,726 & $4.9 \%$ \\
\hline Others & 6,204 & $6.7 \%$ & $2,044,163$ & $24.9 \%$ \\
\hline Total & 91,922 & $100.0 \%$ & $8,225,124$ & $100.0 \%$ \\
\hline
\end{tabular}


Table 3: Tax rates for different entities (1986-87 to 1994-95)

Source: Income tax Web sites, Statistical Abstract of India (various years)

\begin{tabular}{|c|c|c|c|c|c|c|c|c|c|}
\hline & $\begin{array}{r}1986- \\
87 \\
\end{array}$ & $\begin{array}{r}1987- \\
88 \\
\end{array}$ & $\begin{array}{r}1988- \\
89 \\
\end{array}$ & $\begin{array}{r}1989- \\
90 \\
\end{array}$ & $\begin{array}{r}1990- \\
91 \\
\end{array}$ & $\begin{array}{r}1991- \\
92 \\
\end{array}$ & $\begin{array}{r}1992- \\
93 \\
\end{array}$ & $\begin{array}{r}1993- \\
94 \\
\end{array}$ & $\begin{array}{r}1994- \\
95 \\
\end{array}$ \\
\hline \multicolumn{10}{|l|}{ Individuals } \\
\hline 0 to 18,000 & $0 \%$ & $0 \%$ & $0 \%$ & $0 \%$ & $0 \%$ & $0 \%$ & $0 \%$ & $0 \%$ & $0 \%$ \\
\hline 18 to 22,000 & $25 \%$ & $25 \%$ & $25 \%$ & $20 \%$ & $0 \%$ & $0 \%$ & $0 \%$ & $0 \%$ & $0 \%$ \\
\hline 22 to 25,000 & $25 \%$ & $25 \%$ & $25 \%$ & $20 \%$ & $20 \%$ & $20 \%$ & $0 \%$ & $0 \%$ & $0 \%$ \\
\hline 25 to 28,000 & $30 \%$ & $30 \%$ & $30 \%$ & $30 \%$ & $20 \%$ & $20 \%$ & $0 \%$ & $0 \%$ & $0 \%$ \\
\hline 28 to 30,000 & $30 \%$ & $30 \%$ & $30 \%$ & $30 \%$ & $20 \%$ & $20 \%$ & $20 \%$ & $0 \%$ & $0 \%$ \\
\hline 30 to 35,000 & $30 \%$ & $30 \%$ & $30 \%$ & $30 \%$ & $30 \%$ & $30 \%$ & $20 \%$ & $20 \%$ & $0 \%$ \\
\hline 35 to 40,000 & $30 \%$ & $30 \%$ & $30 \%$ & $30 \%$ & $30 \%$ & $30 \%$ & $20 \%$ & $20 \%$ & $0 \%$ \\
\hline 40 to 50,000 & $30 \%$ & $30 \%$ & $30 \%$ & $30 \%$ & $30 \%$ & $30 \%$ & $20 \%$ & $20 \%$ & $20 \%$ \\
\hline 50 to 60,000 & $40 \%$ & $40 \%$ & $40 \%$ & $40 \%$ & $40 \%$ & $40 \%$ & $30 \%$ & $30 \%$ & $20 \%$ \\
\hline 60 to 100,000 & $40 \%$ & $40 \%$ & $40 \%$ & $40 \%$ & $40 \%$ & $40 \%$ & $30 \%$ & $30 \%$ & $30 \%$ \\
\hline 100 to 120,000 & $50 \%$ & $50 \%$ & $50 \%$ & $50 \%$ & $50 \%$ & $50 \%$ & $40 \%$ & $40 \%$ & $30 \%$ \\
\hline 120 to 150,000 & $50 \%$ & $50 \%$ & $50 \%$ & $50 \%$ & $50 \%$ & $50 \%$ & $40 \%$ & $40 \%$ & $40 \%$ \\
\hline$>150,000$ & $50 \%$ & $50 \%$ & $50 \%$ & $50 \%$ & $50 \%$ & $50 \%$ & $40 \%$ & $40 \%$ & $40 \%$ \\
\hline \multicolumn{10}{|l|}{ Partnership firms } \\
\hline 0 to 10,000 & $0 \%$ & $0 \%$ & $0 \%$ & $0 \%$ & $0 \%$ & $0 \%$ & $40 \%$ & $40 \%$ & $40 \%$ \\
\hline 10 to 15,000 & $5 \%$ & $5 \%$ & $5 \%$ & $5 \%$ & $0 \%$ & $0 \%$ & $40 \%$ & $40 \%$ & $40 \%$ \\
\hline 15 to 25,000 & $5 \%$ & $5 \%$ & $5 \%$ & $5 \%$ & $6 \%$ & $6 \%$ & $40 \%$ & $40 \%$ & $40 \%$ \\
\hline 25 to 50,000 & $7 \%$ & $7 \%$ & $7 \%$ & $7 \%$ & $6 \%$ & $6 \%$ & $40 \%$ & $40 \%$ & $40 \%$ \\
\hline 50 to 100,000 & $15 \%$ & $15 \%$ & $15 \%$ & $15 \%$ & $12 \%$ & $12 \%$ & $40 \%$ & $40 \%$ & $40 \%$ \\
\hline$>100,000$ & $24 \%$ & $24 \%$ & $24 \%$ & $24 \%$ & $18 \%$ & $18 \%$ & $40 \%$ & $40 \%$ & $40 \%$ \\
\hline Public-ltd cos (domestic) & $50 \%$ & $50 \%$ & $50 \%$ & $50 \%$ & $40 \%$ & $45 \%$ & $45 \%$ & $45 \%$ & $40 \%$ \\
\hline Private-1td cos (domestic) & $55 \%$ & $55 \%$ & $55 \%$ & $55 \%$ & $45 \%$ & $50 \%$ & $50 \%$ & $50 \%$ & $40 \%$ \\
\hline \multicolumn{10}{|l|}{ Cooperatives } \\
\hline 0 to 10,000 & $15 \%$ & $15 \%$ & $15 \%$ & $15 \%$ & $10 \%$ & $10 \%$ & $10 \%$ & $10 \%$ & $10 \%$ \\
\hline 10 to 20,000 & $25 \%$ & $25 \%$ & $25 \%$ & $25 \%$ & $20 \%$ & $20 \%$ & $20 \%$ & $20 \%$ & $20 \%$ \\
\hline$>20,000$ & $40 \%$ & $40 \%$ & $40 \%$ & $40 \%$ & $35 \%$ & $35 \%$ & $35 \%$ & $35 \%$ & $35 \%$ \\
\hline
\end{tabular}

Union surcharge on income tax:

Partnership firms:

1. For the year 1989-90: 8 percent of income tax if total income exceeds Rs.50,000/-.

2. For the year 1991-92: 12 percent of income tax if taxable income exceeds Rs.75,000/-.

3. For the years 1992-93 and 1993-94: 12 percent of income tax if taxable income exceeds Rs. 1,00,000 Individuals (residents only)

1. For the year 1989-90: 8 percent of income tax if total income exceeds Rs.50,000/-

2. For the years 1990-91 and 1991-92: 12 percent of income tax if taxable income exceeds Rs.75,000/-

3. For the years 1992-93 and 1993-94: 12 percent of income tax if taxable income exceeds Rs.1,00,000/-

4. For the year 1994-95: Nil

Domestic companies:

1. For the year 1989-90: 8 percent of income tax, if total income exceeds Rs50,000/-

2. For the years 1990-91 to 1994-95: 15 percent of income tax, if total income exceeds Rs75,000/-

\section{Coops:}

1. For the year 1989-90: 8 percent of income tax if total income exceeds Rs.50,000/-

2. For the years 1990-91 and 1991-92: 12 percent of income tax if taxable income exceeds Rs.75,000/-

3. For the years 1992-93 and 1993-94: 12 percent of income tax if taxable income exceeds Rs.1,00,000/-

4. For the year 1994-95: Nil 


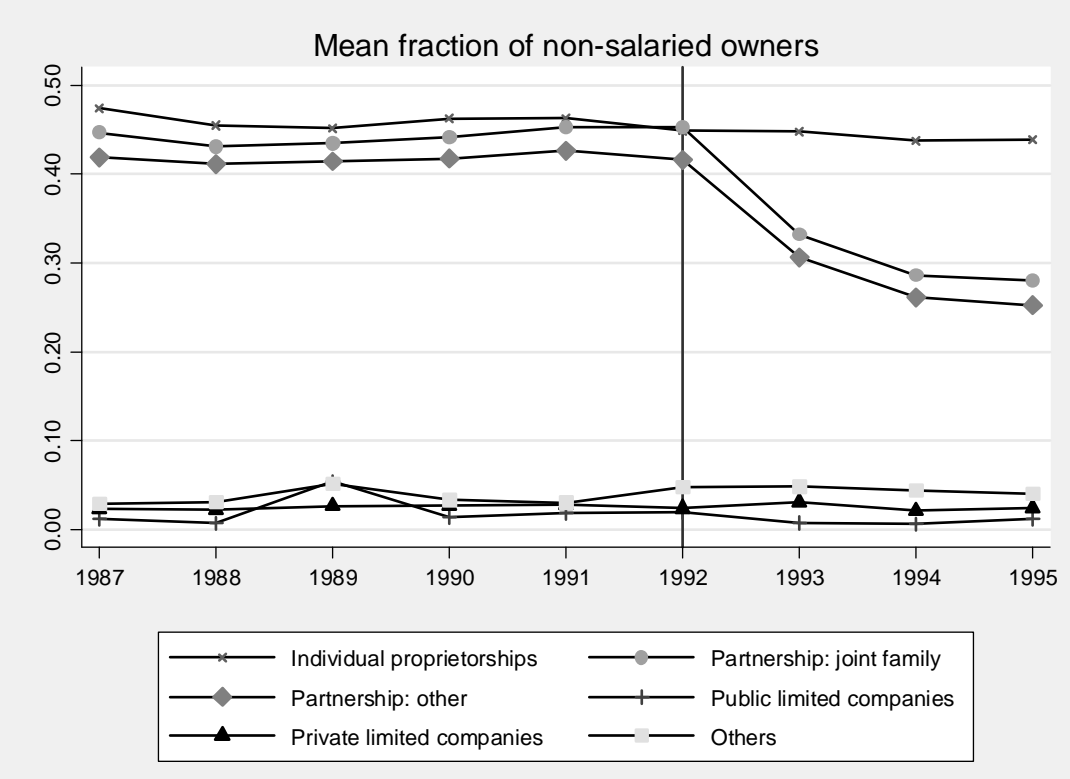

Figure 1: Proprietors and unpaid family members as a fraction of total white-collar employment

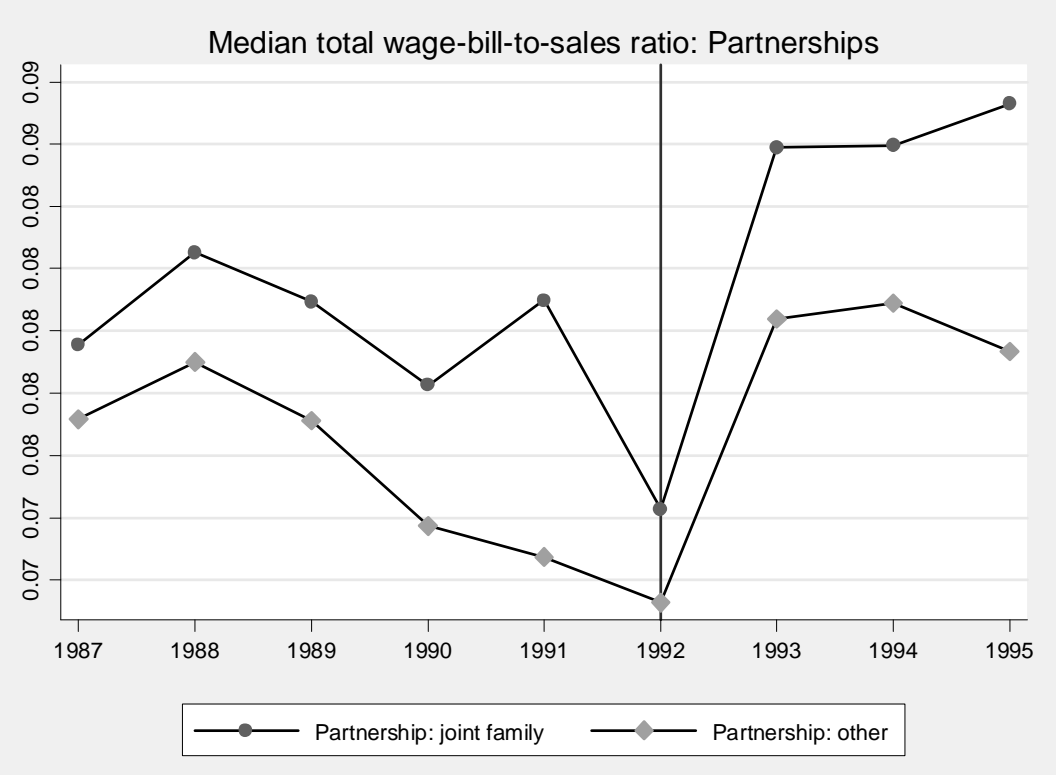

Figure 2b: Median total wage-bill-to-sales ratio for partnership firms

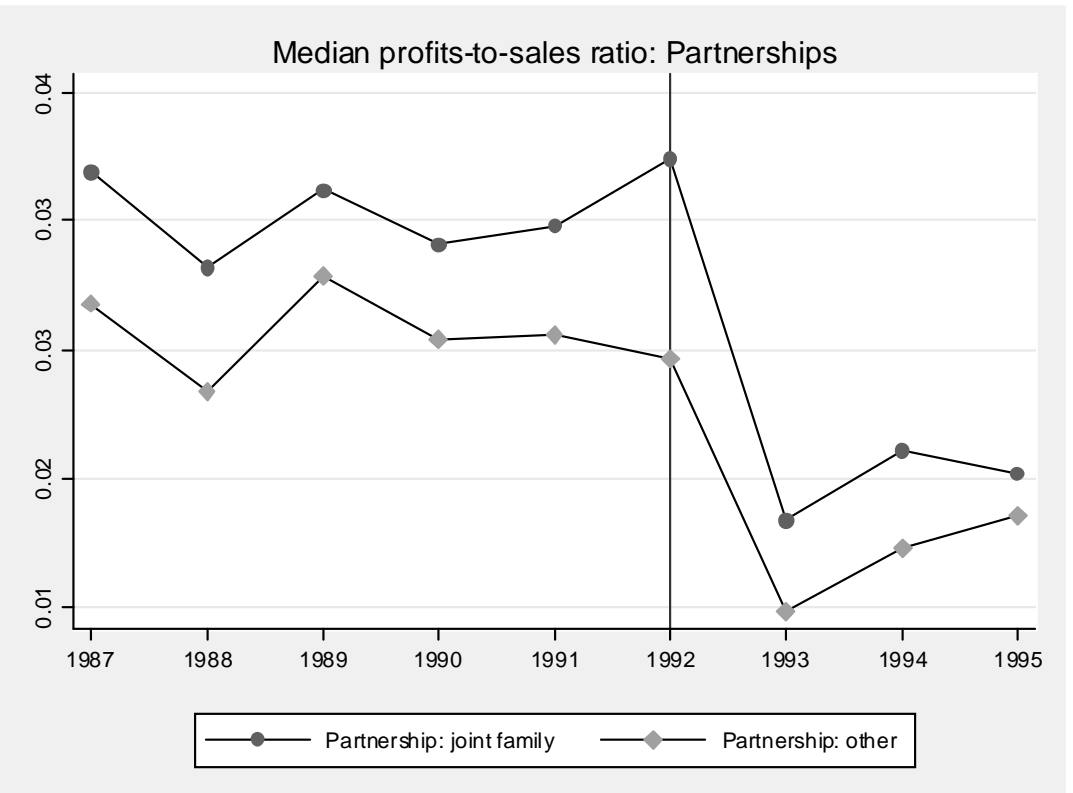

Figure 2a: Median profits-to-sales ratio for partnership firms

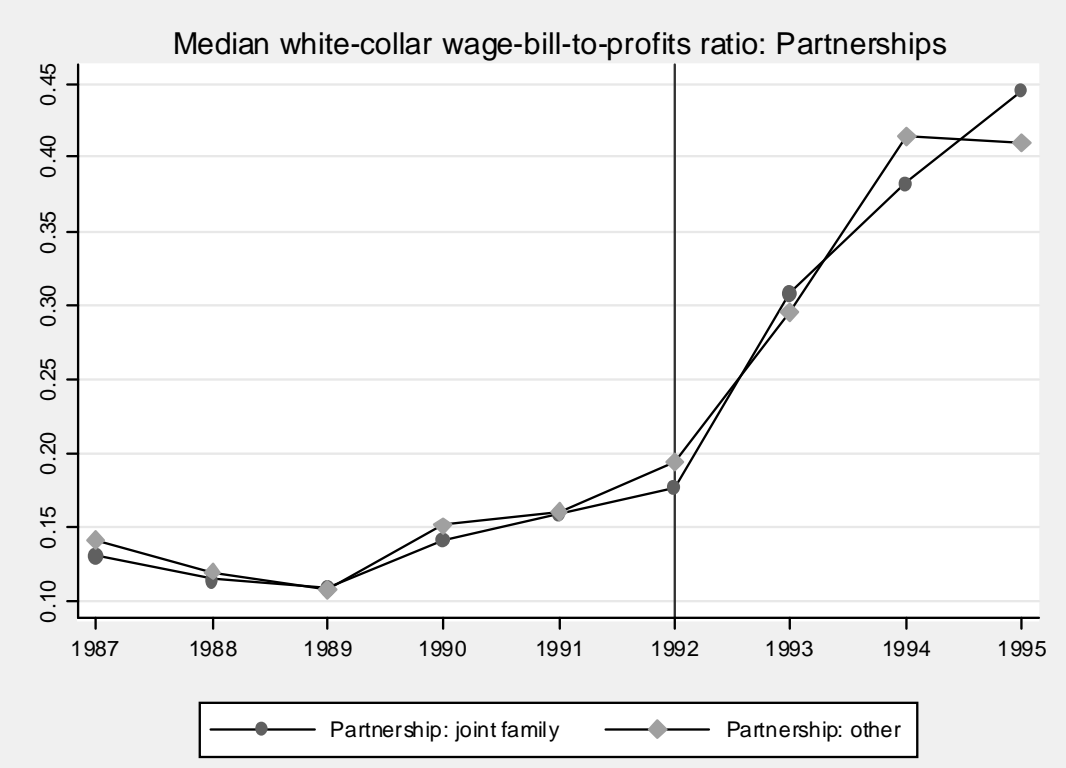

Figure 3: Median white-collar wage-bill-to-profits ratio for partnership firms 
Table 4: Direct effect of the tax law change: Baseline regressions on full sample

All dependent variables are winsorized by 2 percent on both ends of the distribution. D_partnership is a dummy equal to one for partnership firms. Standard errors are clustered at industry level. + significant at $10 \%$; significant at $5 \%$; ** significant at $1 \%$

\begin{tabular}{|c|c|c|c|c|c|c|c|c|}
\hline & $\begin{array}{r}\text { Fraction of } 1 \\
\text { Ow }\end{array}$ & alaried & Profits-to- & es Ratio & $\begin{array}{r}\text { Wage-Bil } \\
\text { Ra }\end{array}$ & o-Sales & $\begin{array}{l}\text { White-Co } \\
\text { Bill-to-Pro }\end{array}$ & $\begin{array}{l}\text { r Wage- } \\
\text { ts Ratio }\end{array}$ \\
\hline & $(1)$ & $(2)$ & (1) & (2) & $(1)$ & (2) & $(1)$ & $(2)$ \\
\hline D_partnership & 0.155 & 0.148 & 0.054 & 0.054 & -0.039 & -0.04 & -0.057 & -0.019 \\
\hline & {$[0.008]^{* *}$} & {$[0.008]^{* *}$} & {$[0.004]^{* *}$} & {$[0.005]^{* *}$} & {$[0.004]^{* *}$} & {$[0.005]^{* *}$} & {$[0.022]^{*}$} & [0.025] \\
\hline$($ Year $=1988) *$ D_partnership & -0.002 & 0.003 & -0.001 & -0.002 & 0 & -0.002 & 0.034 & 0.03 \\
\hline & [0.004] & [0.005] & [0.005] & [0.006] & {$[0.004]$} & [0.005] & [0.035] & [0.039] \\
\hline (Year=1989)*D_partnership & 0.001 & -0.003 & -0.006 & -0.007 & 0 & 0.001 & 0.045 & 0.036 \\
\hline & [0.005] & [0.005] & {$[0.006]$} & [0.006] & [0.005] & [0.006] & [0.032] & [0.042] \\
\hline$(\text { Year }=1990)^{*}$ D_partnership & 0 & 0.002 & -0.013 & -0.01 & 0.005 & 0.005 & -0.017 & -0.035 \\
\hline & [0.004] & [0.005] & {$[0.006]^{*}$} & [0.006] & [0.005] & [0.006] & [0.031] & [0.038] \\
\hline$(\text { Year }=1991)^{*}$ D_partnership & 0.006 & 0.007 & -0.008 & -0.007 & 0.009 & 0.01 & -0.001 & -0.019 \\
\hline & [0.005] & [0.006] & {$[0.005]+$} & [0.006] & {$[0.005]+$} & [0.007] & [0.030] & [0.041] \\
\hline$(\text { Year }=1992)^{*}$ D_partnership & 0.004 & 0.008 & -0.012 & -0.012 & 0.014 & 0.02 & -0.001 & -0.027 \\
\hline & [0.004] & [0.005] & {$[0.005]^{*}$} & {$[0.006]^{*}$} & {$[0.004]^{* *}$} & {$[0.006]^{* *}$} & [0.031] & [0.035] \\
\hline$(\text { Year }=1993)^{*}$ D_partnership & -0.109 & -0.095 & -0.022 & -0.023 & 0.025 & 0.028 & 0.38 & 0.311 \\
\hline & {$[0.010]^{* *}$} & {$[0.008]^{* *}$} & {$[0.007]^{* *}$} & {$[0.007]^{* *}$} & {$[0.005]^{* *}$} & {$[0.007]^{* *}$} & {$[0.040]^{* *}$} & {$[0.044]^{* *}$} \\
\hline$($ Year=1994)*D_partnership & -0.143 & -0.119 & -0.033 & -0.032 & 0.023 & 0.021 & 0.47 & 0.400 \\
\hline & {$[0.008]^{* *}$} & {$[0.008]^{* *}$} & {$[0.005]^{* *}$} & {$[0.006]^{* *}$} & {$[0.004]^{* *}$} & {$[0.005]^{* *}$} & {$[0.040]^{* *}$} & {$[0.046]^{* *}$} \\
\hline$(\text { Year }=1995)^{*}$ D_partnership & -0.155 & -0.131 & -0.032 & -0.035 & 0.029 & 0.030 & 0.465 & 0.381 \\
\hline & {$[0.008]^{* *}$} & {$[0.008]^{* *}$} & {$[0.006]^{* *}$} & {$[0.006]^{* *}$} & {$[0.005]^{* *}$} & {$[0.005]^{* *}$} & {$[0.039]^{* *}$} & {$[0.042]^{* *}$} \\
\hline Constant & 0.228 & 0.219 & -0.045 & -0.033 & 0.198 & 0.189 & 0.41 & 0.501 \\
\hline & {$[0.004]^{* *}$} & {$[0.004]^{* *}$} & {$[0.004]^{* *}$} & {$[0.002]^{* *}$} & {$[0.003]^{* *}$} & {$[0.002]^{* *}$} & {$[0.021]^{* *}$} & {$[0.007]^{* *}$} \\
\hline Year effects & Yes & No & Yes & No & Yes & No & Yes & No \\
\hline State-ind-size effects & Yes & No & Yes & No & Yes & No & Yes & No \\
\hline State-ind-size-year effects & No & Yes & No & Yes & No & Yes & No & Yes \\
\hline Observations & 420200 & 420200 & 350102 & 350102 & 350024 & 350024 & 407515 & 407515 \\
\hline R-squared & 0.40 & 0.46 & 0.16 & 0.13 & 0.28 & 0.25 & 0.08 & 0.08 \\
\hline
\end{tabular}




\section{Log ratio of white to blue-collar wage (skill premium)}
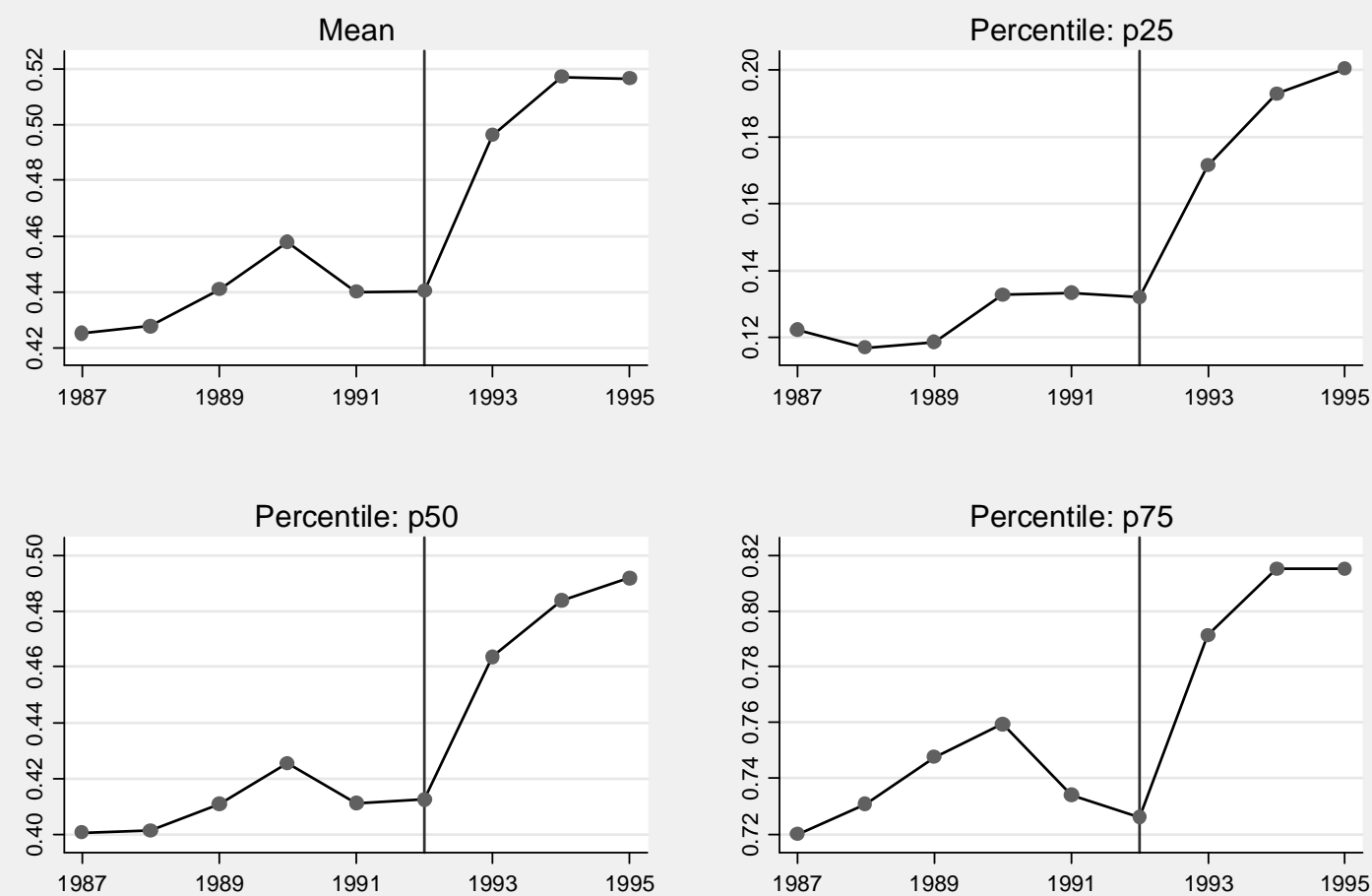

Figure 4: Trends in mean and percentiles of log skill premium
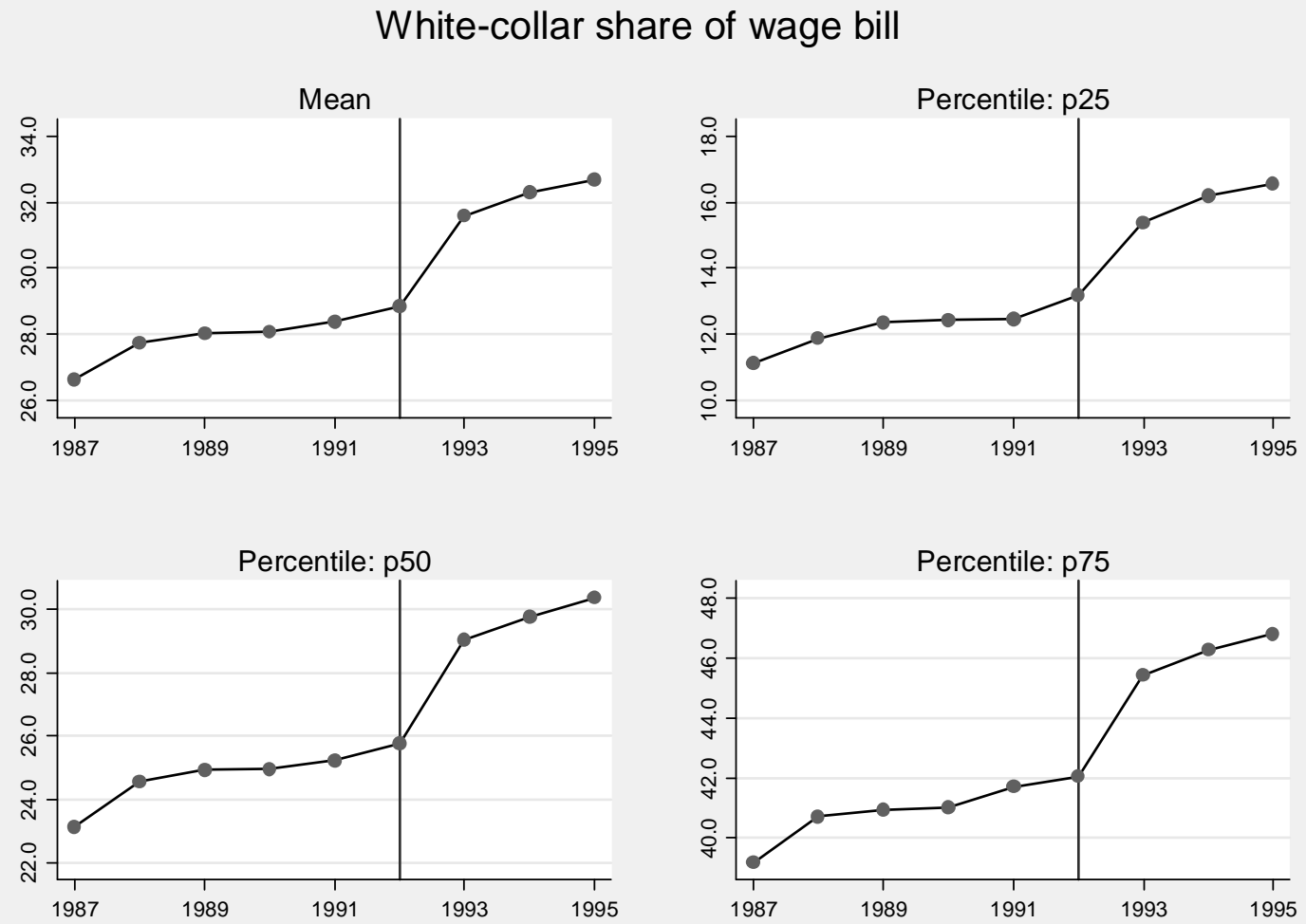

Figure 5: Trends in mean and percentiles of white-collar share of wage bill 


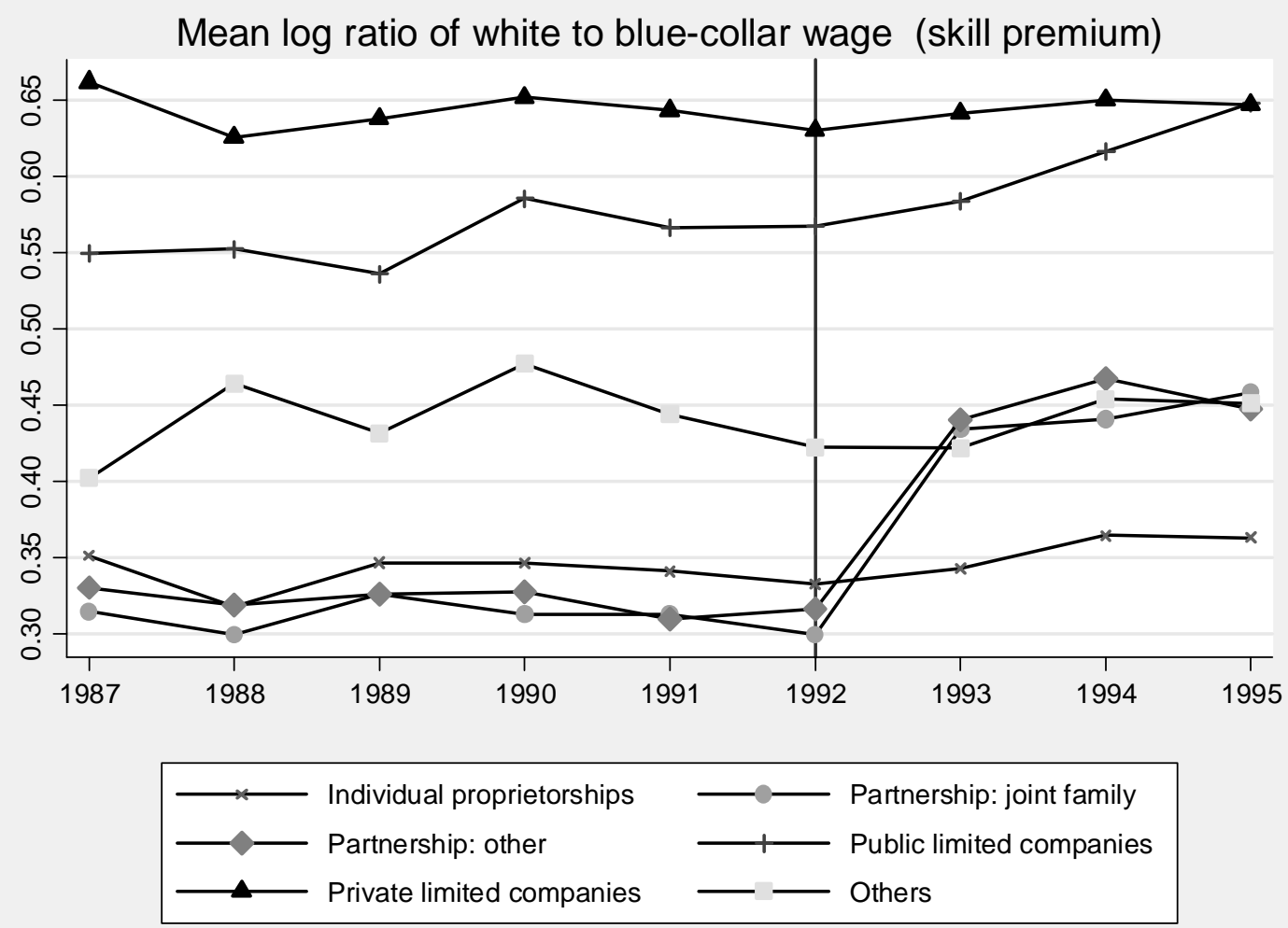

Figure 6: Mean log skill premium by business type

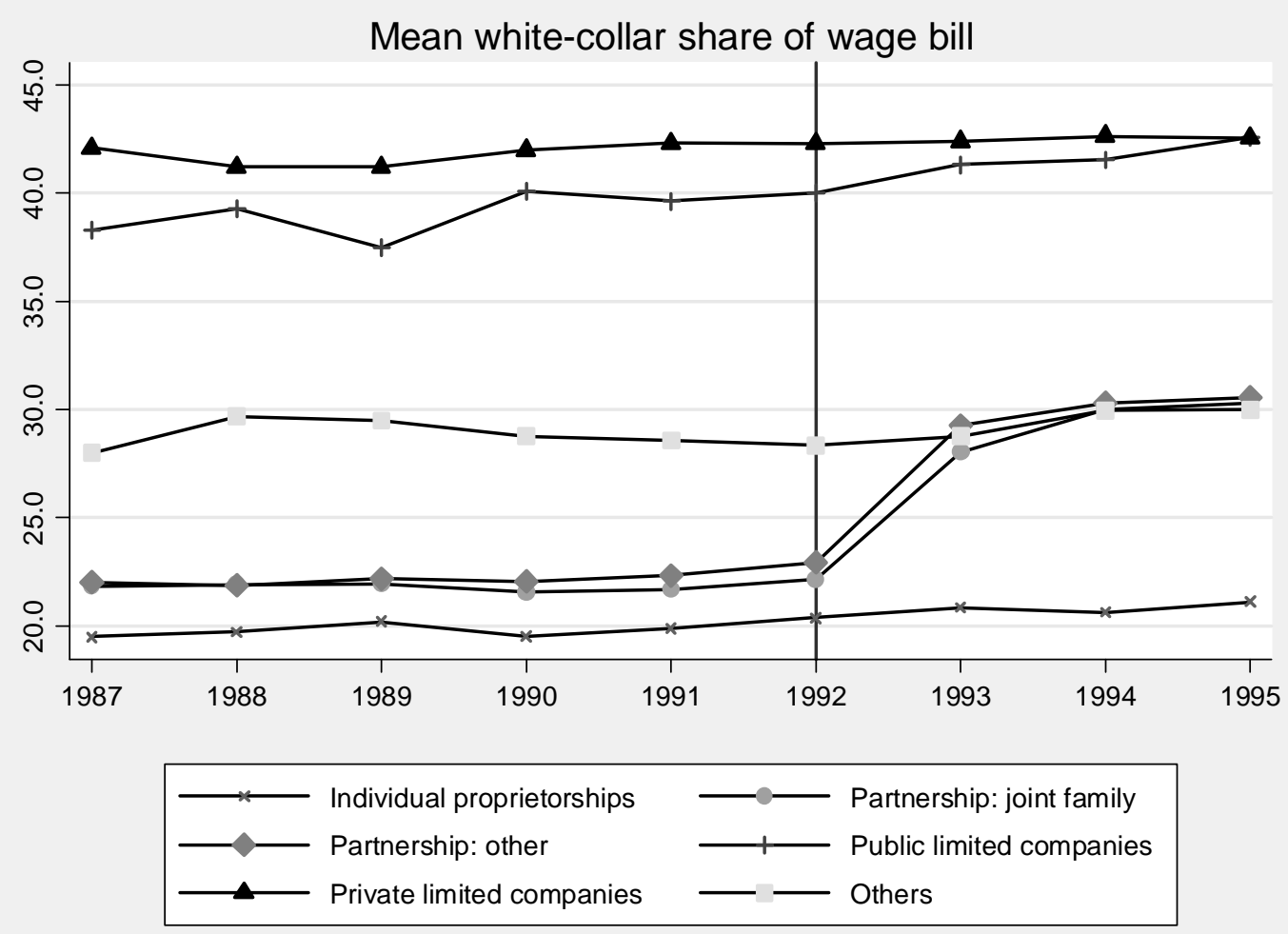

Figure 7: Mean white-collar share of wage bill by business type 
Table 5a: Skill premium trends - controlling for tax law change

All regressions include state-industry-size fixed effects. log_skpr is log ratio of white-collar to blue-collar wage rate. wshare is white-collar share of the wage bill. D_partnership is a dummy equal to one for partnership firms. Standard errors are clustered at industry level. + significant at $10 \%$; ${ }^{*}$ significant at $5 \%$;** significant at $1 \%$

\begin{tabular}{|c|c|c|c|c|c|c|c|c|}
\hline & (1) & $(2)$ & $(3)$ & $(4)$ & $(5)$ & $(6)$ & $(7)$ & $(8)$ \\
\hline Dependent variable & log_skpr & log_skpr & log_skpr & log_skpr & wshare & wshare & wshare & wshare \\
\hline \multirow[t]{2}{*}{ Year $=1988$} & -0.015 & & -0.015 & & 0.179 & & 0.324 & \\
\hline & {$[0.004]^{* *}$} & & {$[0.007]^{*}$} & & {$[0.161]$} & & {$[0.273]$} & \\
\hline \multirow[t]{2}{*}{ Year=1989 } & 0.001 & & -0.008 & & 0.189 & & 0.156 & \\
\hline & [0.005] & & [0.007] & & [0.179] & & {$[0.286]$} & \\
\hline \multirow[t]{2}{*}{ Year $=1990$} & 0.012 & & 0.011 & & 0.416 & & 0.421 & \\
\hline & {$[0.006]^{*}$} & & {$[0.007]+$} & & {$[0.194]^{*}$} & & [0.299] & \\
\hline \multirow[t]{2}{*}{ Year $=1991$} & 0.002 & & -0.002 & & 0.665 & & 0.566 & \\
\hline & [0.005] & & [0.007] & & {$[0.242]^{* *}$} & & [0.345] & \\
\hline \multirow[t]{2}{*}{ Year $=1992$} & -0.002 & & -0.015 & & 1.073 & & 0.735 & \\
\hline & [0.006] & & {$[0.008]+$} & & {$[0.214]^{* *}$} & & {$[0.342]^{*}$} & \\
\hline \multirow[t]{2}{*}{ Year=1993 } & 0.063 & & -0.006 & & 4.349 & & 1.08 & \\
\hline & {$[0.007]^{* *}$} & & {$[0.008]$} & & {$[0.262]^{* *}$} & & {$[0.336]^{* *}$} & \\
\hline \multirow[t]{2}{*}{ Year $=1994$} & 0.082 & & 0.011 & & 4.899 & & 1.219 & \\
\hline & {$[0.009]^{* *}$} & & {$[0.008]$} & & {$[0.304]^{* *}$} & & {$[0.381]^{* *}$} & \\
\hline \multirow[t]{2}{*}{ Year=1995 } & 0.076 & & 0.012 & & 5.257 & & 1.638 & \\
\hline & {$[0.007]^{* *}$} & & [0.008] & & {$[0.353]^{* *}$} & & {$[0.448]^{* *}$} & \\
\hline \multirow[t]{2}{*}{ tpd=1 $(1991,92)$} & & -0.001 & & -0.007 & & 0.663 & & 0.417 \\
\hline & & [0.003] & & [0.005] & & {$[0.154]^{* *}$} & & {$[0.201]^{*}$} \\
\hline \multirow[t]{2}{*}{$\operatorname{tpd}=2(1993,94,95)$} & & 0.073 & & 0.008 & & 4.63 & & 1.083 \\
\hline & & {$[0.005]^{* *}$} & & {$[0.005]$} & & {$[0.239]^{* *}$} & & {$[0.233]^{* *}$} \\
\hline \multirow[t]{2}{*}{ D_partnership } & & & -0.138 & -0.138 & & & -6.06 & -6.334 \\
\hline & & & {$[0.009]^{* *}$} & {$[0.007]^{* *}$} & & & {$[0.562]^{* *}$} & {$[0.471]^{* *}$} \\
\hline \multirow[t]{2}{*}{$(\text { Year }=1988)^{*}$ D_partnership } & & & 0 & & & & -0.342 & \\
\hline & & & [0.008] & & & & [0.303] & \\
\hline \multirow[t]{2}{*}{$(\text { Year }=1989)^{*}$ D_partnership } & & & 0.011 & & & & -0.232 & \\
\hline & & & {$[0.010]$} & & & & [0.297] & \\
\hline \multirow[t]{2}{*}{$(\text { Year }=1990)^{*}$ D_partnership } & & & -0.009 & & & & -0.491 & \\
\hline & & & [0.010] & & & & [0.337] & \\
\hline \multirow[t]{2}{*}{$(\text { Year }=1991)^{*}$ D_partnership } & & & -0.008 & & & & -0.432 & \\
\hline & & & [0.008] & & & & [0.363] & \\
\hline \multirow[t]{2}{*}{$($ Year $=1992) *$ D_partnership } & & & 0.008 & & & & -0.132 & \\
\hline & & & {$[0.010]$} & & & & {$[0.357]$} & \\
\hline \multirow[t]{2}{*}{$($ Year=1993)*D_partnership } & & & 0.127 & & & & 5.908 & \\
\hline & & & {$[0.011]^{* *}$} & & & & {$[0.414]^{* *}$} & \\
\hline \multirow[t]{2}{*}{$($ Year=1994)*D_partnership } & & & 0.13 & & & & 6.784 & \\
\hline & & & {$[0.012]^{* *}$} & & & & {$[0.472]^{* *}$} & \\
\hline \multirow[t]{2}{*}{$(\text { Year }=1995)^{*}$ D_partnership } & & & 0.114 & & & & 6.682 & \\
\hline & & & {$[0.011]^{* *}$} & & & & {$[0.494]^{* *}$} & \\
\hline \multirow[t]{2}{*}{$(\operatorname{tpd}=1)^{*}$ D_partnership } & & & & 0.001 & & & & -0.01 \\
\hline & & & & [0.006] & & & & [0.214] \\
\hline \multirow[t]{2}{*}{$(\operatorname{tpd}=2)^{*}$ D_partnership } & & & & 0.123 & & & & 6.724 \\
\hline & & & & {$[0.007]^{* *}$} & & & & {$[0.339]^{* *}$} \\
\hline Constant & 0.414 & 0.414 & 0.488 & 0.486 & 26.537 & 26.744 & 29.884 & 30.119 \\
\hline & {$[0.005]^{* *}$} & {$[0.002]^{* *}$} & {$[0.007]^{* *}$} & {$[0.004]^{* *}$} & {$[0.176]^{* *}$} & {$[0.104]^{* *}$} & {$[0.372]^{* *}$} & {$[0.238]^{* *}$} \\
\hline Observations & 385531 & 385531 & 385531 & 385531 & 421561 & 421561 & 421561 & 421561 \\
\hline R-squared & 0.17 & 0.17 & 0.18 & 0.18 & 0.33 & 0.33 & 0.34 & 0.34 \\
\hline
\end{tabular}




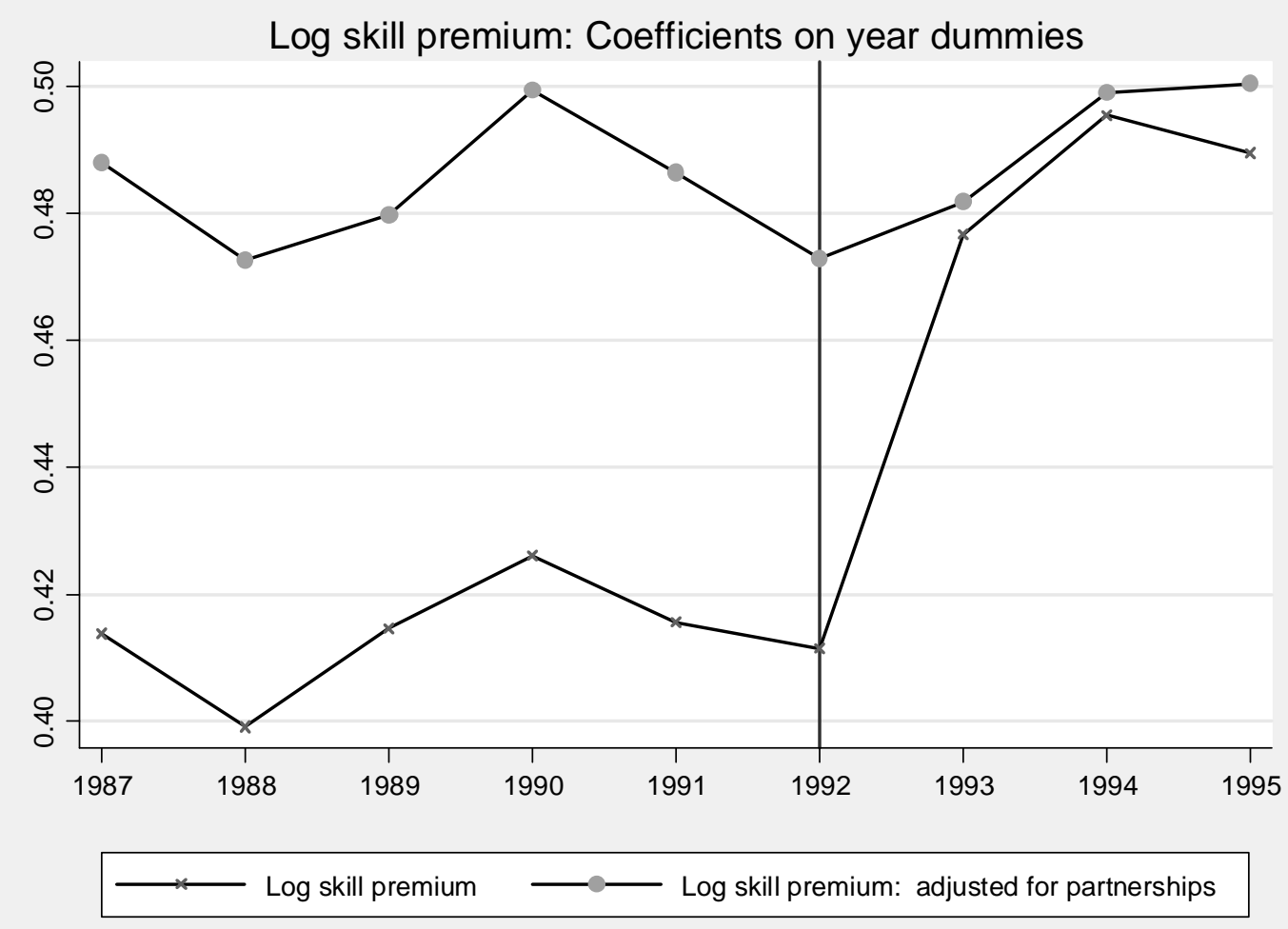

Figure 8: Coefficient on year dummies on log skill premium from Table 4 (with and without controls for partnership firms)

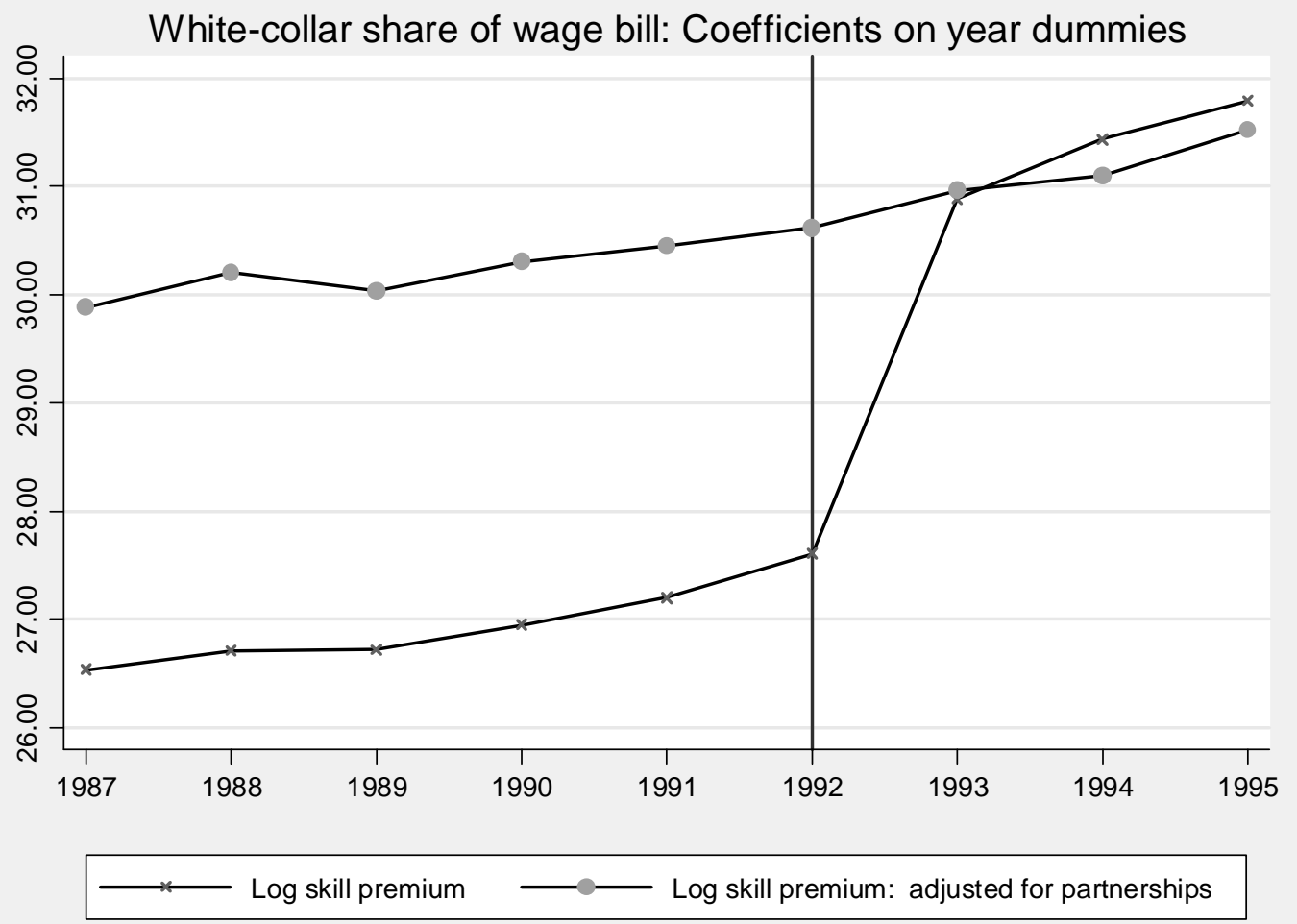

Figure 9: Coefficient on year dummies on white-collar share of wage bill from Table 4 (with and without controls for partnership firms) 
Table 5b: Log skill premium (ratio of white-collar to blue-collar wage rate) trends - alternative explanations

All regressions include state-industry-size fixed effects. D_partnership is a dummy equal to one for partnership firms. Tariff drop (1990-92) is the drop in tariff between 1990 and 1992 for 3-digit industries. Exports-to-output ratio and imports-to-output ratio are pre-91 averages for 3-digit industries. FDI deregulation dummy is equal to one for industries where foreign investment up to 51 percent was permitted in 1991. Capital-output ratio is the log of the ratio of real capital to real value added. Distance to frontier is the ratio of maximum (over all 4-digit industries) industry mean log total factor productivity to the industry mean total factor productivity. Standard errors are clustered at industry level. + significant at $10 \%$; ${ }^{*}$ significant at $5 \%$; ** significant at $1 \%$

\begin{tabular}{|c|c|c|c|c|c|c|c|c|c|}
\hline & (1) & (2) & (3) & (4) & (5) & (6) & (7) & (8) & (9) \\
\hline \multirow[t]{2}{*}{$\operatorname{tpd}=1(1991,92)$} & -0.001 & -0.007 & -0.005 & -0.002 & -0.003 & 0.001 & -0.002 & -0.026 & -0.029 \\
\hline & [0.003] & [0.005] & [0.007] & [0.003] & [0.003] & {$[0.004]$} & [0.003] & {$[0.027]$} & [0.031] \\
\hline \multirow[t]{2}{*}{$\operatorname{tpd}=2(1993,94,95)$} & 0.073 & 0.008 & 0.086 & 0.075 & 0.074 & 0.074 & 0.068 & 0.148 & 0.011 \\
\hline & {$[0.005]^{* *}$} & {$[0.005]$} & {$[0.009]^{* *}$} & {$[0.005]^{* *}$} & {$[0.006]^{* *}$} & {$[0.006]^{* *}$} & {$[0.005]^{* *}$} & {$[0.044]^{* *}$} & [0.047] \\
\hline \multirow[t]{2}{*}{ D_partnership } & & -0.138 & & & & & & & -0.143 \\
\hline & & {$[0.007]^{* *}$} & & & & & & & {$[0.006]^{* *}$} \\
\hline \multirow{2}{*}{$(\operatorname{tpd}=1) *$ D_partnership } & & 0.001 & & & & & & & 0.002 \\
\hline & & [0.006] & & & & & & & [0.006] \\
\hline \multirow[t]{2}{*}{$(\operatorname{tpd}=2)^{*} \mathrm{D} \_$partnership } & & 0.123 & & & & & & & 0.121 \\
\hline & & {$[0.007]^{* *}$} & & & & & & & {$[0.007]^{* *}$} \\
\hline \multirow[t]{2}{*}{$(\operatorname{tpd}=1)^{*}$ Tariff drop (1990-92) } & & & 0.012 & & & & & & 0.013 \\
\hline & & & [0.023] & & & & & & [0.027] \\
\hline \multirow[t]{2}{*}{$(\operatorname{tpd}=2)^{*}$ Tariff drop (1990-92) } & & & -0.044 & & & & & & -0.036 \\
\hline & & & {$[0.034]$} & & & & & & [0.033] \\
\hline \multirow[t]{2}{*}{$(\operatorname{tpd}=1)^{*}$ Exports-to-output ratio (pre-91) } & & & & -0.002 & & & & & -0.003 \\
\hline & & & & {$[0.002]$} & & & & & [0.003] \\
\hline \multirow[t]{2}{*}{$(\operatorname{tpd}=2)^{*}$ Exports-to-output ratio (pre-91) } & & & & -0.006 & & & & & -0.004 \\
\hline & & & & {$[0.006]$} & & & & & [0.005] \\
\hline \multirow[t]{2}{*}{$(\operatorname{tpd}=1)^{*}$ Imports-to-output ratio (pre-91) } & & & & & 0.004 & & & & 0.019 \\
\hline & & & & & [0.015] & & & & [0.017] \\
\hline \multirow[t]{2}{*}{$(\operatorname{tpd}=2)^{*}$ Imports-to-output ratio (pre-91) } & & & & & 0.002 & & & & 0.034 \\
\hline & & & & & {$[0.014]$} & & & & {$[0.012]^{* *}$} \\
\hline \multirow[t]{2}{*}{$(\mathrm{tpd}=1)^{*}$ FDI deregulation dummy } & & & & & & -0.007 & & & -0.009 \\
\hline & & & & & & [0.007] & & & [0.007] \\
\hline \multirow[t]{2}{*}{$(\operatorname{tpd}=2)^{*}$ FDI deregulation dummy } & & & & & & -0.007 & & & -0.006 \\
\hline & & & & & & {$[0.008]$} & & & [0.008] \\
\hline \multirow[t]{2}{*}{ Capital-output ratio } & & & & & & & 0.008 & & 0.009 \\
\hline & & & & & & & {$[0.001]^{* *}$} & & {$[0.001]^{* *}$} \\
\hline \multirow[t]{2}{*}{$(\operatorname{tpd}=1)^{*}$ Capital-output ratio } & & & & & & & -0.001 & & -0.001 \\
\hline & & & & & & & [0.002] & & [0.002] \\
\hline \multirow[t]{2}{*}{$(\operatorname{tpd}=2)^{*}$ Capital-output ratio } & & & & & & & 0.001 & & -0.002 \\
\hline & & & & & & & {$[0.002]$} & & [0.002] \\
\hline \multirow[t]{2}{*}{$(\operatorname{tpd}=1)^{*}$ Distance to frontier } & & & & & & & & 0.035 & 0.022 \\
\hline & & & & & & & & {$[0.040]$} & [0.043] \\
\hline \multirow[t]{2}{*}{$(\mathrm{tpd}=2) *$ Distance to frontier } & & & & & & & & -0.109 & 0.006 \\
\hline & & & & & & & & {$[0.064]+$} & [0.064] \\
\hline \multirow[t]{2}{*}{ Constant } & 0.414 & 0.486 & 0.421 & 0.421 & 0.421 & 0.422 & 0.417 & 0.407 & 0.498 \\
\hline & {$[0.002]^{* *}$} & {$[0.004]^{* *}$} & {$[0.002]^{* *}$} & {$[0.002]^{* *}$} & {$[0.002]^{* *}$} & {$[0.002]^{* *}$} & {$[0.002]^{* *}$} & {$[0.002]^{* *}$} & {$[0.004]^{* *}$} \\
\hline Observations & 385531 & 385531 & 354524 & 359722 & 359722 & 385531 & 325510 & 364722 & 300598 \\
\hline R-squared & 0.17 & 0.18 & 0.16 & 0.17 & 0.17 & 0.17 & 0.18 & 0.17 & 0.18 \\
\hline
\end{tabular}


Table 5c: White-collar share of wage bill trends - alternative explanations

All regressions include state-industry-size fixed effects. D_partnership is a dummy equal to one for partnership firms. Tariff drop (1990-92) is the drop in tariff between 1990 and 1992 for 3-digit industries. Exports-to-output ratio and imports-to-output ratio are pre-91 averages for 3-digit industries. FDI deregulation dummy is equal to one for industries where foreign investment up to 51 percent was permitted in 1991. Capital-output ratio is the log of the ratio of real capital to real value added. Distance to frontier is the ratio of maximum (over all 4-digit industries) industry mean log total factor productivity to the industry mean total factor productivity. Standard errors are clustered at industry level. + significant at $10 \%$; ${ }^{*}$ significant at $5 \%$; ** significant at $1 \%$

\begin{tabular}{|c|c|c|c|c|c|c|c|c|c|}
\hline & (1) & (2) & (3) & (4) & (5) & (6) & (7) & (8) & (9) \\
\hline \multirow[t]{2}{*}{ tpd=1 $(1991,92)$} & 0.663 & 0.417 & 0.25 & 0.608 & 0.531 & 0.599 & 0.46 & -0.38 & -1.229 \\
\hline & {$[0.154]^{* *}$} & {$[0.201]^{*}$} & [0.308] & {$[0.148]^{* *}$} & {$[0.159]^{* *}$} & {$[0.187]^{* *}$} & {$[0.156]^{* *}$} & [1.356] & [1.479] \\
\hline \multirow[t]{2}{*}{$\operatorname{tpd}=2(1993,94,95)$} & 4.63 & 1.083 & 4.474 & 4.73 & 4.526 & 4.492 & 4.039 & 10.221 & 0.55 \\
\hline & {$[0.239]^{* *}$} & {$[0.233]^{* *}$} & {$[0.462]^{* *}$} & {$[0.228]^{* *}$} & {$[0.282]^{* *}$} & {$[0.310]^{* *}$} & {$[0.285]^{* *}$} & {$[2.621]^{* *}$} & [3.069] \\
\hline \multirow[t]{2}{*}{ D_partnership } & & -6.334 & & & & & & & -6.584 \\
\hline & & {$[0.471]^{* *}$} & & & & & & & {$[0.448]^{* *}$} \\
\hline \multirow[t]{2}{*}{$(\operatorname{tpd}=1)^{*}$ D_partnership } & & -0.01 & & & & & & & 0.13 \\
\hline & & {$[0.214]$} & & & & & & & [0.204] \\
\hline \multirow[t]{2}{*}{$(\operatorname{tpd}=2)^{*}$ D_partnership } & & 6.724 & & & & & & & 6.467 \\
\hline & & {$[0.339]^{* *}$} & & & & & & & {$[0.361]^{* *}$} \\
\hline \multirow[t]{2}{*}{$(\operatorname{tpd}=1)^{*}$ Tariff drop $(1990-92)$} & & & 1.285 & & & & & & 1.367 \\
\hline & & & [0.856] & & & & & & [0.938] \\
\hline \multirow[t]{2}{*}{$(\operatorname{tpd}=2)^{*}$ Tariff drop (1990-92) } & & & 0.715 & & & & & & 2.513 \\
\hline & & & [1.744] & & & & & & [1.844] \\
\hline \multirow[t]{2}{*}{$(\operatorname{tpd}=1)^{*}$ Exports-to-output ratio (pre-91) } & & & & -0.002 & & & & & 0.017 \\
\hline & & & & [0.038] & & & & & [0.046] \\
\hline \multirow[t]{2}{*}{$(\mathrm{tpd}=2)^{*}$ Exports-to-output ratio (pre-91) } & & & & -0.338 & & & & & -0.164 \\
\hline & & & & {$[0.275]$} & & & & & [0.170] \\
\hline \multirow[t]{2}{*}{$(\mathrm{tpd}=1)^{*}$ Imports-to-output ratio (pre-91) } & & & & & 0.701 & & & & 0.122 \\
\hline & & & & & {$[0.573]$} & & & & [0.625] \\
\hline \multirow[t]{2}{*}{$(\mathrm{tpd}=2)^{*}$ Imports-to-output ratio (pre-91) } & & & & & 1.345 & & & & 1.386 \\
\hline & & & & & [1.001] & & & & [0.969] \\
\hline \multirow[t]{2}{*}{$(\mathrm{tpd}=1)^{*} \mathrm{FDI}$ deregulation dummy } & & & & & & 0.247 & & & 0.459 \\
\hline & & & & & & [0.305] & & & [0.293] \\
\hline \multirow[t]{2}{*}{$(\mathrm{tpd}=2)^{*}$ FDI deregulation dummy } & & & & & & 0.526 & & & 0.976 \\
\hline & & & & & & [0.413] & & & {$[0.425]^{*}$} \\
\hline \multirow[t]{2}{*}{ Capital-output ratio } & & & & & & & 0.798 & & 0.852 \\
\hline & & & & & & & {$[0.084]^{* *}$} & & {$[0.057]^{* *}$} \\
\hline \multirow[t]{2}{*}{$(\operatorname{tpd}=1)^{*}$ Capital-output ratio } & & & & & & & 0.044 & & 0.098 \\
\hline & & & & & & & [0.062] & & [0.063] \\
\hline \multirow[t]{2}{*}{$(\operatorname{tpd}=2)^{*}$ Capital-output ratio } & & & & & & & 0.346 & & 0.245 \\
\hline & & & & & & & {$[0.062]^{* *}$} & & {$[0.070]^{* *}$} \\
\hline \multirow[t]{2}{*}{$(\operatorname{tpd}=1)^{*}$ Distance to frontier } & & & & & & & & 1.464 & 1.063 \\
\hline & & & & & & & & [1.949] & [2.086] \\
\hline \multirow[t]{2}{*}{$(\mathrm{tpd}=2)^{*}$ Distance to frontier } & & & & & & & & -8.075 & -1.386 \\
\hline & & & & & & & & {$[3.752]^{*}$} & [4.264] \\
\hline \multirow[t]{2}{*}{ Constant } & 26.744 & 30.119 & 26.31 & 26.703 & 26.699 & 26.742 & 26.751 & 26.648 & 30.193 \\
\hline & {$[0.104]^{* *}$} & {$[0.238]^{* *}$} & {$[0.102]^{* *}$} & {$[0.102]^{* *}$} & {$[0.102]^{* *}$} & {$[0.103]^{* *}$} & {$[0.129]^{* *}$} & {$[0.100]^{* *}$} & {$[0.199]^{* *}$} \\
\hline Observations & 421561 & 421561 & 388270 & 394162 & 394162 & 421561 & 355710 & 399328 & 328979 \\
\hline R-squared & 0.33 & 0.34 & 0.33 & 0.33 & 0.33 & 0.33 & 0.36 & 0.33 & 0.36 \\
\hline
\end{tabular}




\section{Appendix}

Appendix Table 1a: Fraction of Partnership firms, and entry rates (1987-1995)1

\begin{tabular}{lrrr}
\hline Year & $\begin{array}{c}\text { Fraction } \\
\text { Partnerships }\end{array}$ & $\begin{array}{c}\text { Fraction New } \\
\text { (Total) }\end{array}$ & $\begin{array}{c}\text { Fraction New } \\
\text { (Partnerships) }\end{array}$ \\
\hline 1987 & $55.5 \%$ & $2.4 \%$ & $1.1 \%$ \\
1988 & $55.1 \%$ & $2.7 \%$ & $1.2 \%$ \\
1989 & $52.6 \%$ & $2.5 \%$ & $1.1 \%$ \\
1990 & $51.1 \%$ & $2.5 \%$ & $1.0 \%$ \\
1991 & $50.0 \%$ & $2.9 \%$ & $1.1 \%$ \\
1992 & $48.3 \%$ & $2.6 \%$ & $1.0 \%$ \\
1993 & $47.0 \%$ & $2.0 \%$ & $0.6 \%$ \\
1994 & $46.0 \%$ & $2.6 \%$ & $0.9 \%$ \\
1995 & $44.7 \%$ & $2.7 \%$ & $0.9 \%$ \\
\hline
\end{tabular}

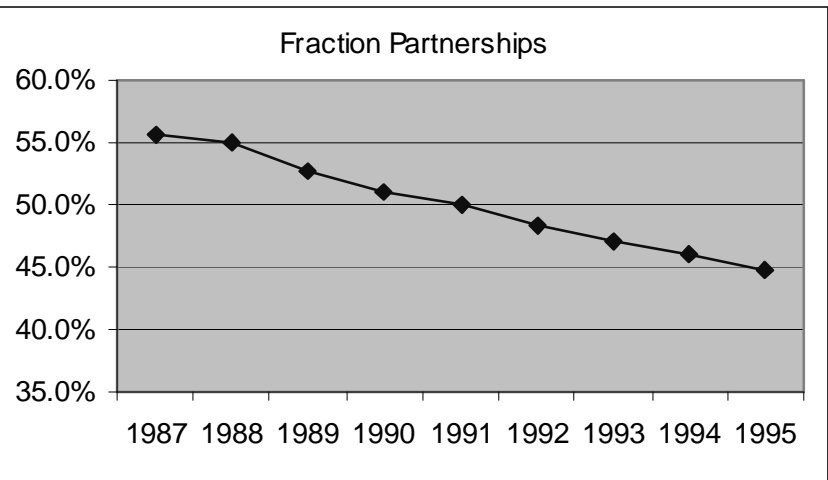

Appendix Table 1b: Analysis of the choice of partnership organizational form (1987-1995)1

\begin{tabular}{lrrr}
\hline & \multicolumn{1}{c}{$(1)$} & \multicolumn{1}{c}{$(2)$} & \multicolumn{1}{c}{$(3)$} \\
& Linear & \multicolumn{1}{c}{ Probit } & \multicolumn{1}{c}{ Logit } \\
\hline Log(Gross Sales) & -0.044 & -0.128 & -0.208 \\
& {$[0.004]^{* *}$} & {$[0.020]^{* *}$} & {$[0.032]^{* *}$} \\
Log(Age of Plant: Winsorized by 0.5\%) & & 0.077 & 0.126 \\
& & {$[0.027]^{* *}$} & {$[0.044]^{* *}$} \\
Trend (= Year - 1985) & -0.007 & -0.019 & -0.03 \\
& {$[0.001]^{* *}$} & {$[0.005]^{* *}$} & {$[0.008]^{* *}$} \\
tpd=1 (1991,92) & 0.003 & -0.001 & -0.003 \\
& {$[0.004]$} & {$[0.011]$} & {$[0.018]$} \\
tpd=2 (1993,94,95) & 0.003 & -0.004 & -0.007 \\
& {$[0.006]$} & {$[0.017]$} & {$[0.028]$} \\
Constant & 1.21 & 1.887 & 3.066 \\
& {$[0.063]^{* *}$} & {$[0.250]^{* *}$} & {$[0.406]^{* *}$} \\
State-industry fixed effects & Yes & No & No \\
Observations & 350102 & 350103 & 350103 \\
R-squared & 0.23 & & \\
\hline
\end{tabular}

\footnotetext{
${ }^{1}$ Appendix Tables $1 \mathrm{a}$ and $1 \mathrm{~b}$, and Figure 1 relate to footnote 22 in the text. There is a downward trend in the fraction of partnerships in the sample. There is no change in this trend around the time of the tax reform (1992). Also there is no significant change around 1992 in the fraction of entrants that are partnerships. Table $1 \mathrm{~b}$ indicates no significant change in the propensity to be incorporated as a partnership after the 1992 tax law change.
} 


\section{Appendix}

Appendix Table 2: Regression estimates of the direct effects of the tax law change: Variation of response across age and location ${ }^{2}$

"Old" establishments are defined as those "old" that are at least 10-years old. Urban establishments are those located in areas coded as urban. Other year dummies and year dummies interacted with the partnership dummy are omitted. Standard errors are clustered at industry level. + significant at $10 \% ;{ }^{*}$ significant at $5 \% ;{ }^{* *}$ significant

\begin{tabular}{|c|c|c|c|c|c|c|c|c|c|c|c|c|}
\hline & \multicolumn{3}{|c|}{$\begin{array}{c}\text { Fraction of Non-Salaried } \\
\text { Owners }\end{array}$} & \multicolumn{3}{|c|}{ Profits-to-Sales Ratio } & \multicolumn{3}{|c|}{ Wage-Bill-to-Sales Ratio } & \multicolumn{3}{|c|}{$\begin{array}{c}\text { White-Collar Wage-Bill-to- } \\
\text { Profits Ratio }\end{array}$} \\
\hline & 1 & 2 & 3 & 1 & 2 & 3 & 1 & 2 & 3 & 1 & 2 & 3 \\
\hline & Full & $\begin{array}{l}\text { Urban } \\
\text { only }\end{array}$ & $\begin{array}{l}\text { Old } \\
\text { only }\end{array}$ & Full & $\begin{array}{r}\text { Urban } \\
\text { only }\end{array}$ & $\begin{array}{l}\text { Old } \\
\text { only }\end{array}$ & Full & $\begin{array}{r}\text { Urban } \\
\text { only }\end{array}$ & $\begin{array}{l}\text { Old } \\
\text { only }\end{array}$ & Full & $\begin{array}{r}\text { Urban } \\
\text { only }\end{array}$ & $\begin{array}{l}\text { Old } \\
\text { only }\end{array}$ \\
\hline \multirow[t]{2}{*}{$(y r==1993) * D$ _partner } & -0.097 & -0.12 & -0.102 & -0.027 & -0.022 & -0.02 & 0.031 & 0.03 & 0.028 & 0.332 & 0.355 & 0.399 \\
\hline & {$[0.016]^{* *}$} & {$[0.012]^{* *}$} & {$[0.026]^{* *}$} & {$[0.007]^{* *}$} & {$[0.007]^{* *}$} & {$[0.009]^{*}$} & {$[0.006]^{* *}$} & {$[0.007]^{* *}$} & {$[0.008]^{* *}$} & {$[0.041]^{* *}$} & {$[0.048]^{* *}$} & {$[0.058]^{* *}$} \\
\hline \multirow[t]{2}{*}{$(y r==1994) *$ D_partner } & -0.133 & -0.148 & -0.15 & -0.035 & -0.03 & -0.025 & 0.026 & 0.022 & 0.021 & 0.422 & 0.44 & 0.484 \\
\hline & {$[0.008]^{* *}$} & {$[0.009]^{* *}$} & {$[0.011]^{* *}$} & {$[0.006]^{* *}$} & {$[0.006]^{* *}$} & {$[0.008]^{* *}$} & {$[0.005]^{* *}$} & {$[0.006]^{* *}$} & {$[0.008]^{* *}$} & {$[0.041]^{* *}$} & {$[0.048]^{* *}$} & {$[0.054]^{* *}$} \\
\hline \multirow[t]{2}{*}{$(y r==1995)^{*}$ D_partner } & -0.148 & -0.164 & -0.161 & -0.037 & -0.032 & -0.031 & 0.033 & 0.03 & 0.034 & 0.402 & 0.392 & 0.43 \\
\hline & {$[0.008]^{* *}$} & {$[0.008]^{* *}$} & {$[0.011]^{* *}$} & {$[0.006]^{* *}$} & {$[0.006]^{* *}$} & {$[0.008]^{* *}$} & {$[0.005]^{* *}$} & {$[0.006]^{* *}$} & {$[0.006]^{* *}$} & {$[0.039]^{* *}$} & {$[0.046]^{* *}$} & {$[0.062]^{* *}$} \\
\hline \multirow[t]{2}{*}{ Constant } & 0.2 & 0.2 & 0.198 & -0.033 & -0.024 & -0.017 & 0.19 & 0.189 & 0.214 & 0.499 & 0.55 & 0.564 \\
\hline & {$[0.006]^{* *}$} & {$[0.005]^{* *}$} & {$[0.007]^{* *}$} & {$[0.002]^{* *}$} & {$[0.002]^{* *}$} & {$[0.002]^{* *}$} & {$[0.002]^{* *}$} & {$[0.002]^{* *}$} & {$[0.002]^{* *}$} & {$[0.006]^{* *}$} & {$[0.008]^{* *}$} & {$[0.008]^{* *}$} \\
\hline State-ind-year effects & Yes & Yes & Yes & Yes & Yes & Yes & Yes & Yes & Yes & Yes & Yes & Yes \\
\hline Observations & 420200 & 296768 & 239979 & 350102 & 251318 & 198079 & 350024 & 251249 & 198008 & 407515 & 289757 & 230063 \\
\hline R-squared & 0.26 & 0.29 & 0.28 & 0.13 & 0.12 & 0.16 & 0.25 & 0.24 & 0.30 & 0.08 & 0.09 & 0.11 \\
\hline Number of clusters & 1097 & 1019 & 950 & 1045 & 977 & 908 & 1045 & 977 & 908 & 1088 & 1013 & 941 \\
\hline
\end{tabular}

\footnotetext{
${ }^{2}$ Appendix table 2 relates to footnote 37 and 38 in the text. Refer text for a discussion of these results.
} 
Appendix Figure 2a: Log sales of partnership firms (relative to others in the same stateindustry) ${ }^{3}$

This figure plots the coefficient on year dummies interacted with a partnership dummy, in a regression where the dependent variable is Log (Gross Sales). State-industry-year effects were included in this regression, so the coefficients can be interpreted as the change in Log (Gross Sales) for partnership firms relative to other firms within the same state and industry.

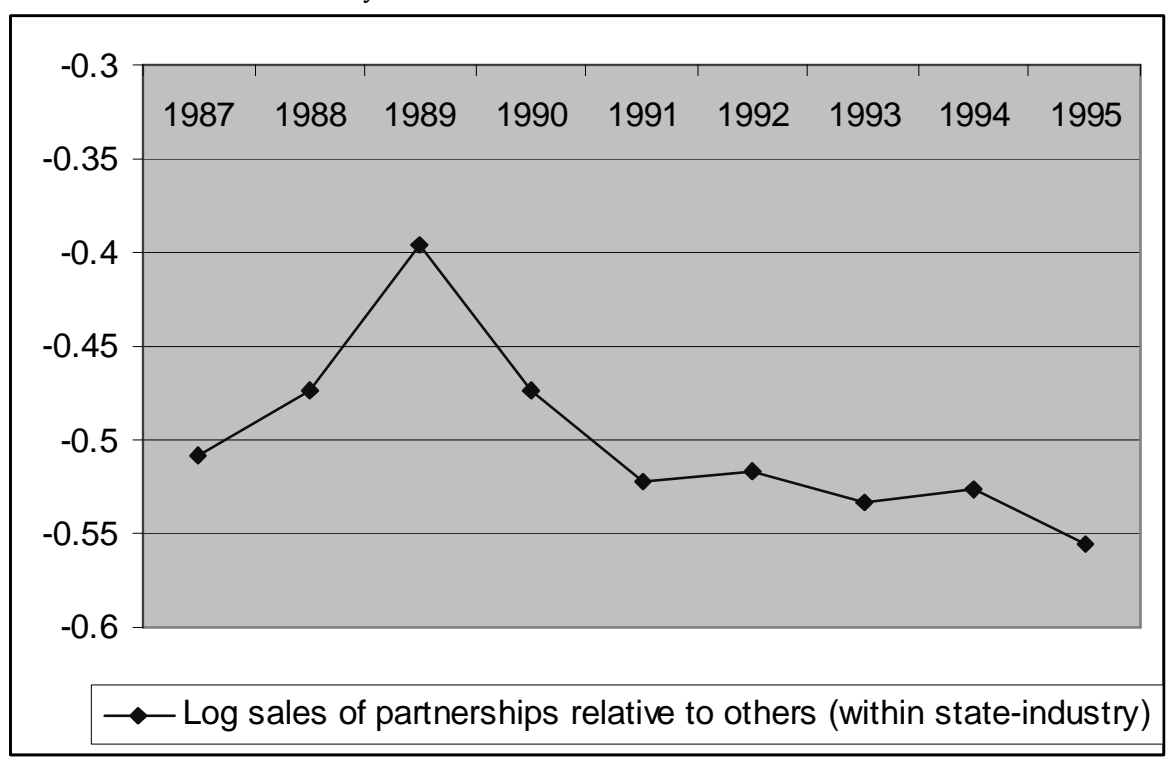

Appendix Figure 2b: Log employment and value added of partnership firms (relative to others in the same state-industry) $)^{3}$

This figure plots the coefficients on year dummies interacted with a partnership dummy, from regressions where the dependent variables are Log (Total Employment) and Log(Value Added). State-industry-year effects were included in this regression, so the coefficients can be interpreted as the change in the dependent variables for partnerships firms relative to other firms within the same state and industry.

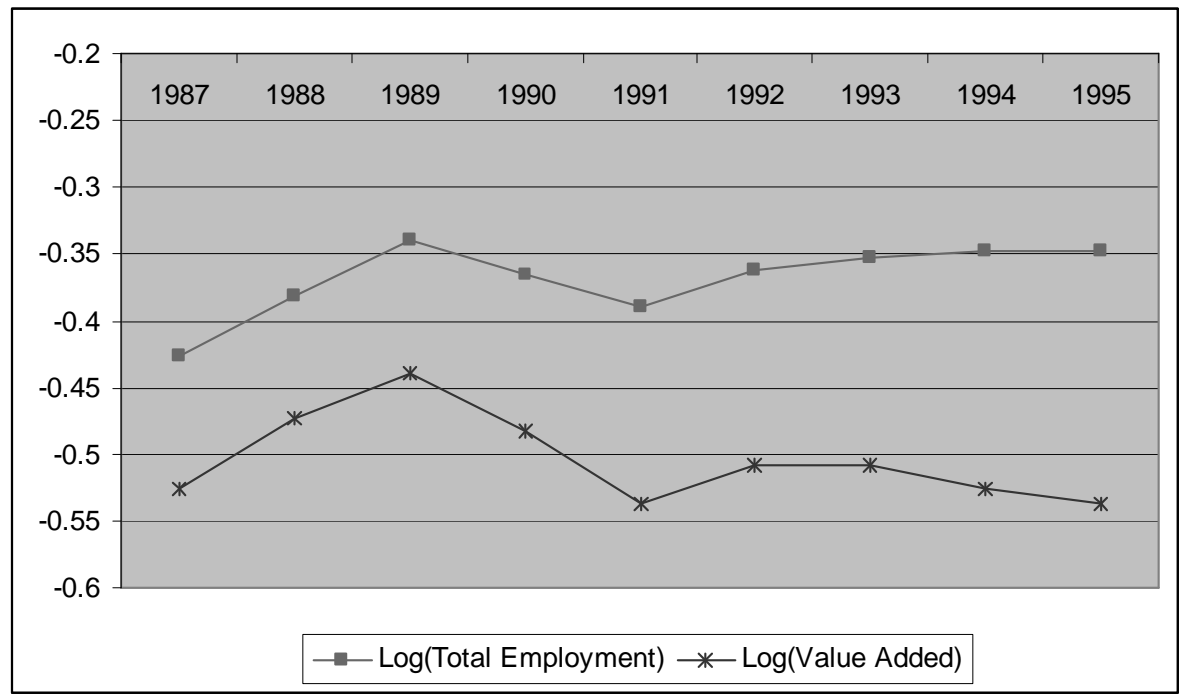

\footnotetext{
${ }^{3}$ Figures $2 \mathrm{a}$ and $2 \mathrm{~b}$ relate to footnote 42 . We find no evidence of significant jumps in sales or total employment or value added, which would have accompanied certain types of tax avoidance measures.
} 